\title{
A MATTER OF SURVIVAL: \\ WHY UNACCOMPANIED CHILDREN LEAVE THE NORTHERN TRIANGLE OF CENTRAL AMERICA
}

by

Lidia-Gabriela Jarmasz

BA, Linguistics and Medieval Studies, University of Ottawa, 2004

MA, Linguistics, University of Ottawa, 2006

\author{
A Major Research Paper \\ presented to Ryerson University \\ in partial fulfilment of the requirements for the degree of \\ Master of Arts \\ in the Program of \\ Immigration and Settlement Studies
}

Toronto, Ontario, Canada, 2018

(C) Lidia-Gabriela Jarmasz, 2018 


\section{AUTHOR'S DECLARATION FOR ELECTRONIC SUBMISSION OF A MAJOR RESEARCH PAPER (MRP)}

I hereby declare that I am the sole author of this Major Research Paper. This is a true copy of the MRP, including any required final revisions, as accepted by my examiners.

I authorize Ryerson University to lend this MRP to other institutions or individuals for the purpose of scholarly research.

I further authorize Ryerson University to reproduce this MRP by photocopying or by other means, in total or in part, at the request of other institutions or individuals for the purpose of scholarly research.

I understand that my MRP may be made electronically available to the public.

Lidia-Gabriela Jarmasz 


\title{
A MATTER OF SURVIVAL: \\ WHY UNACCOMPANIED CHILDREN LEAVE THE NORTHERN TRIANGLE OF \\ CENTRAL AMERICA
}

\section{Lidia-Gabriela Jarmasz \\ Master of Arts 2018}

Immigration and Settlement Studies

Ryerson University

\begin{abstract}
This MRP applies a grounded theory approach to a scoping review of a range of sources examining the factors driving the migration of unaccompanied children from the Northern Triangle of Central America. Four principal drivers are identified in the literature; of these, two represent push factors in the country of origin: violence and dismal economic conditions; the other two - family reunification and a perception of ease of entry into the destination countrycan be construed as pull factors. I argue that the push factors are the main cause of the migration of unaccompanied children, while the pull factors represent enabling factors that facilitate this migration. Further, I also contend that, for this migration flow, violence and economic factors form a vicious cycle and therefore cannot easily be teased apart. This case therefore challenges traditional models of migration that assume a dichotomy between voluntary and forced migration.
\end{abstract}

Key words: unaccompanied child migrants; Northern Triangle of Central America; drivers of migration; survival migration; push and pull factors 


\section{ACKNOWLEDGEMENTS}

First and foremost, I must thank Professor Francis Hare for agreeing to supervise this MRP without even knowing me. He immediately understood my vision for this project, and I am grateful for his wisdom, experience, and especially, his great calm.

Thank you also to Professor Henry Parada for enthusiastically agreeing to act as second reader, in spite of his busy schedule and numerous commitments.

Professor Myer Siemiatycki was also generous with his encouragement, reassuring words, and flexibility, which allowed me to neglect my work obligations in order to complete the MRP on time.

Returning to school after a ten-year hiatus was a greater challenge than I ever expected. I had the good fortune, however, of being accompanied by exceptionally kind and smart classmates with varied life experiences. Without the encouragement and interest of Amelia Galizia, this MRP may very well never have seen the light of day. On a more personal level, my new friendships with Adriana Espinosa de los Monteros Romo and Carissa Groot-Nibbelink provided many bright spots in the past year.

I am also grateful for the friends and family that I have almost entirely neglected for the past twelve months. Thank you for waiting, without judgement, for me to come out at the other end.

And finally, I owe the most to the person who also happens to have suffered the most from this adventure, my infinitely patient partner/cheerleader/sounding board/personal chef Gerard Van Herk. I never, ever would have finished this degree without you, and you know it. 


\section{DEDICATION}

To my aunts, Irena Mińkowska, Małgorzata Jarmasz, and Joanna Jarmasz, my father's last living siblings, who were displaced from their home as children during World War II.

To my mother, Mercedes Jarmasz, who came to Canada from Honduras when she was still practically a child, and never expected to stay permanently.

And to the Central American children and youth who are currently embarking on dangerous and uncertain journeys in order to survive, as well as to those who are unable to escape. 


\section{TABLE OF CONTENTS}

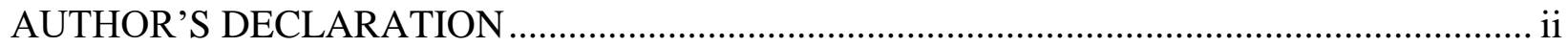

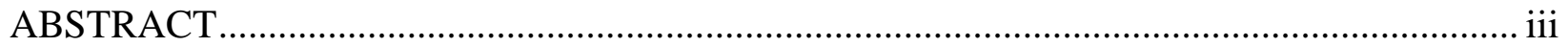

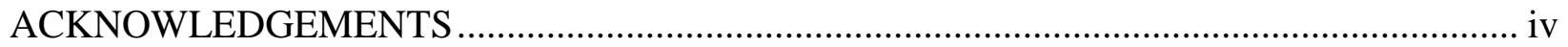

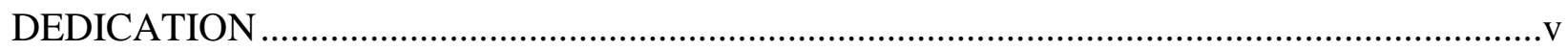

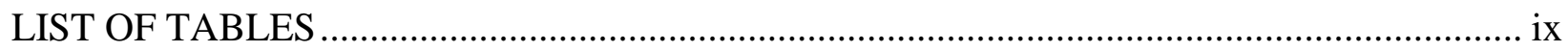

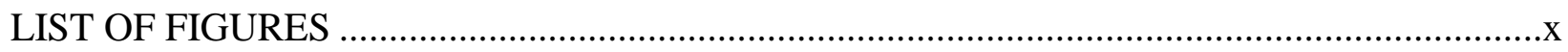

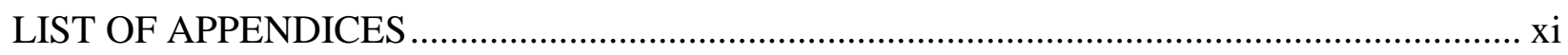

LIST OF ABBREVIATIONS ......................................................................................

CHAPTER 1. INTRODUCTION. ..............................................................................

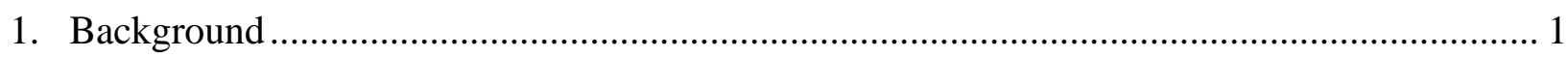

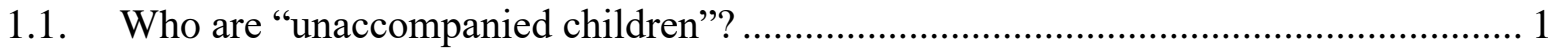

1.2. Characteristics of the NTCA countries.................................................................... 2

2. Unaccompanied child migrants from the NTCA ...................................................... 6

3. Debates about the causes of the migration of unaccompanied children from the NTCA.....10

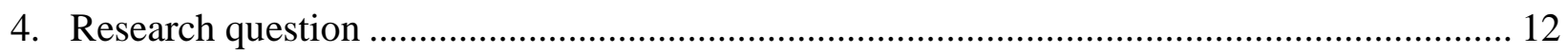

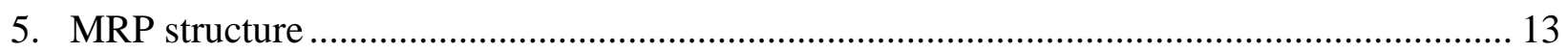

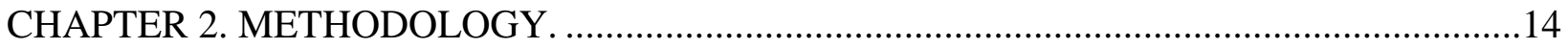

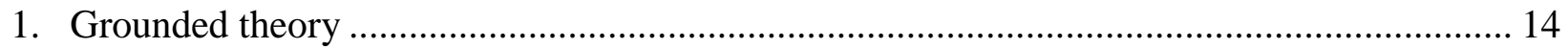

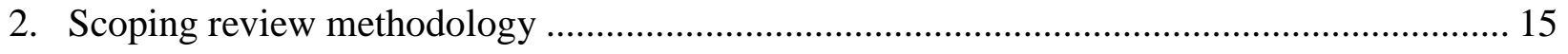

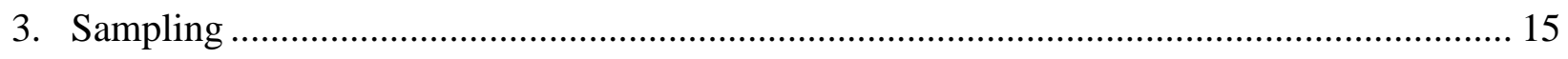

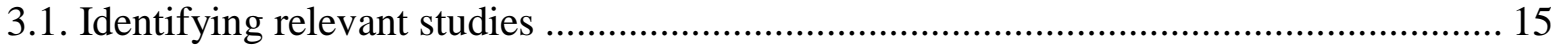

3.2. Inclusion and exclusion criteria for study selection ............................................ 17

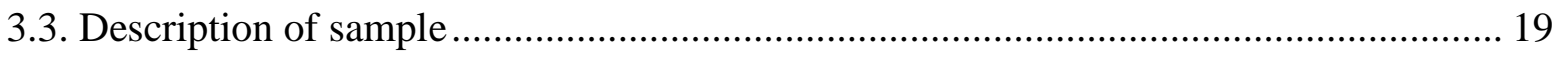

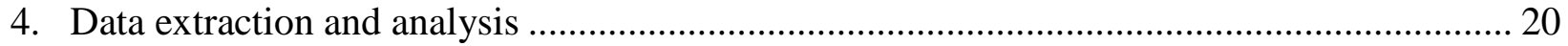

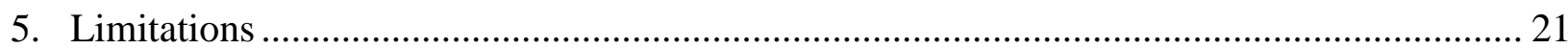

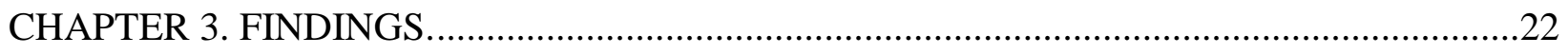

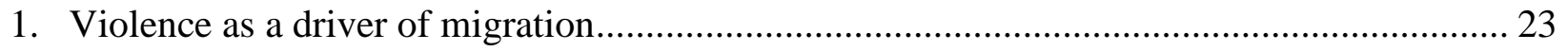

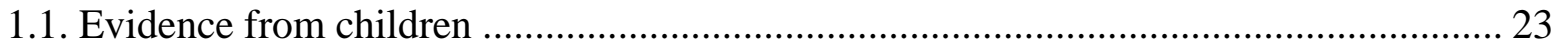




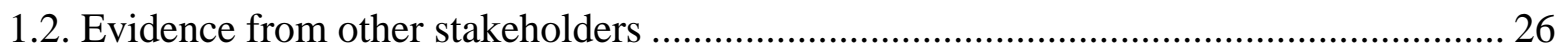

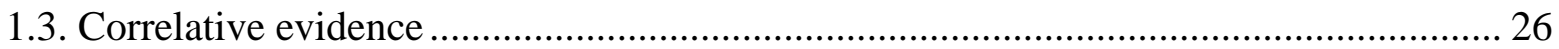

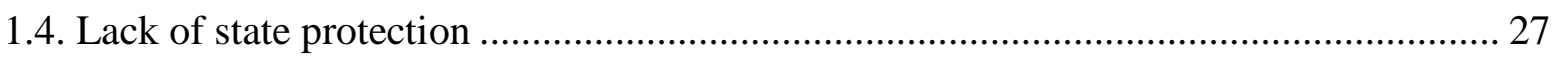

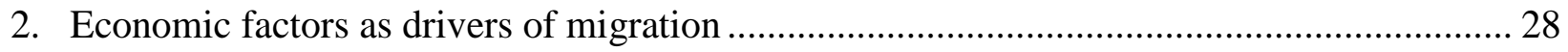

2.1. Evidence from children ................................................................................. 29

2.2. Evidence from other stakeholders .................................................................... 30

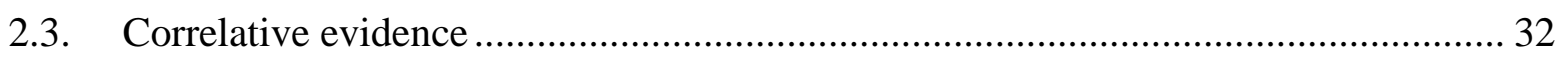

3. Parental absence as a driver of migration ……………................................................. 34

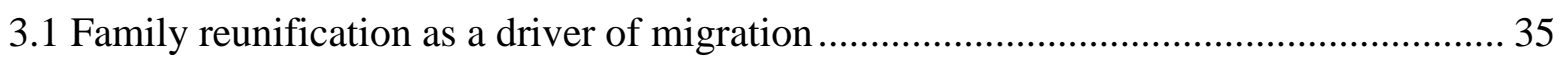

3.1.1. Evidence from children .................................................................................... 35

3.1.2. Evidence from other stakeholders................................................................... 36

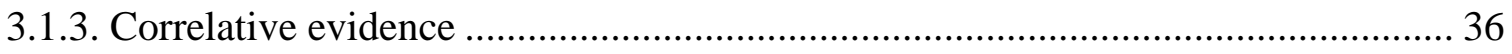

3.2. Family breakdown as a driver of migration................................................................. 37

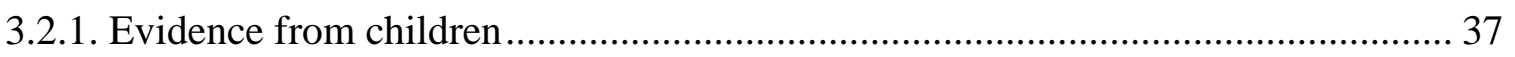

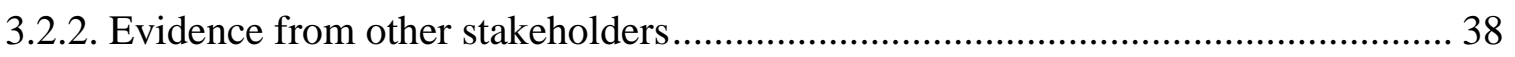

4. Perceived ease of entry into the destination country as a driver of migration ......................... 39

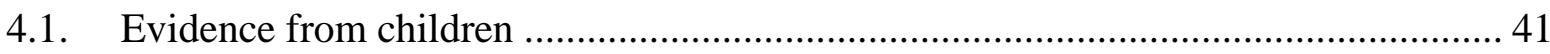

4.2. Evidence from other stakeholders ........................................................................ 42

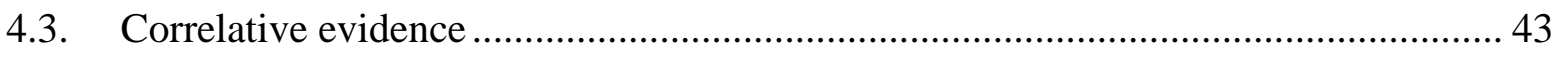

5. Intersections between demographic characteristics and drivers of migration ......................... 44

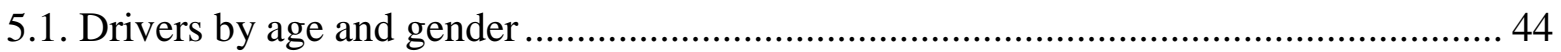

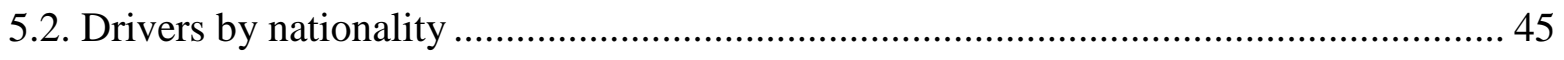

5.3. The migration of specific groups .................................................................................. 46

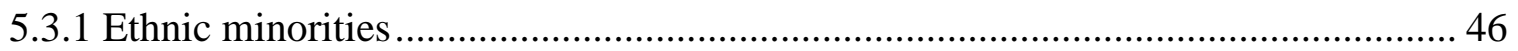

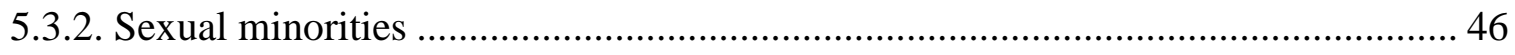

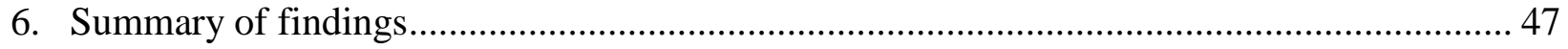

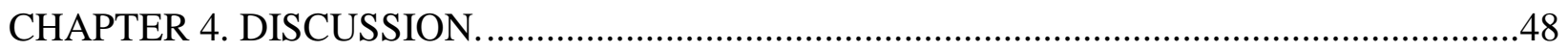

1. Push and pull factors in the migration of unaccompanied children from the NTCA ............. 48

1.1. Perceptions of ease of entry to the United States as an enabling factor ......................... 49

1.2. Family reunification as an enabling factor ………….................................................... 50

2. Are unaccompanied children seeking better economic conditions or fleeing violence? ........ 52 
2.1. Evidence from children 53

2.2. Correlative evidence 55

2.3. The interrelatedness of violence and economic factors ................................................... 56

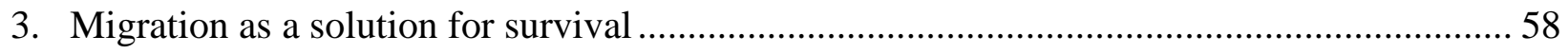

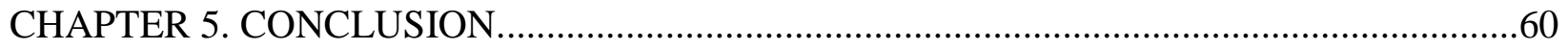

APPENDIX: LIST OF SOURCES INCLUDED IN SCOPING REVIEW SAMPLE ...................63

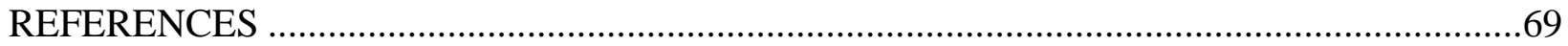




\section{LIST OF TABLES}

Table 1. U.S. apprehensions of unaccompanied children, 2011-2018, per self-reported country of

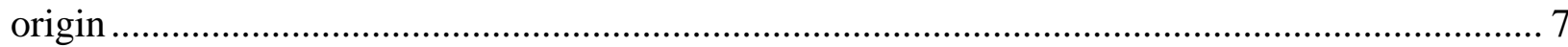

Table 2. Summary of English-language search queries in RULA catalogue ........................... 16

Table 3. Summary of Spanish-language search queries in RULA catalogue ........................... 17

Table 4. Distribution of database items by language and type ........................................... 19

Table 5. Distribution of database items by language and source of evidence .......................... 20

Table 6. Correlative evidence of a link between homicide rates and migration........................ 26

Table 7. Summary of economic indicators examined in sample .......................................... 33 


\section{LIST OF FIGURES}

Figure 1. Map highlighting the position of the Northern Triangle within Central America ......... 2

Figure 2. Apprehensions of unaccompanied children in the United States, 2011-2018 ............. 8

Figure 3. Vicious cycle of violence and poor economic conditions in the NTCA .................... 57 


\section{LIST OF APPENDICES}

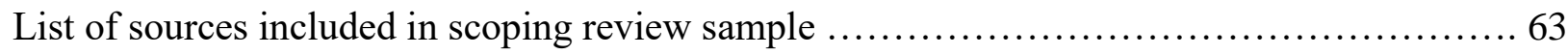




\section{LIST OF ABBREVIATIONS}

CONAPO

DACA

EPIC

GAO

KIND \& HRCFMC

NTCA

RULA

TVPRA

UNHCR

UNODC

USCBP

WFP \& IOM

WRC
Consejo Nacional de Población [National Population Council of Mexico]

Deferred Action for Childhood Arrivals

El Paso Intelligence Center

U.S. Government Accountability Office

Kids in Need of Defense \& Human Rights Center Fray Matías de Córdova

Northern Triangle of Central America

Ryerson University Library and Archives

Trafficking Victims Protection Reauthorization Act

United Nations High Commissioner for Refugees

United Nations Office on Drugs and Crime

U.S. Customs and Border Protection

United Nations World Food Programme \& International Organization for Migration

Women's Refugee Commission 


\section{CHAPTER 1. INTRODUCTION.}

In February of 2016, an article in The Guardian (Stillman, 2016) introduced me to the phenomenon of children migrating without their parents from the Northern Triangle of Central America (henceforth, NTCA), composed of Guatemala, El Salvador, and Honduras. It vividly described the dangers (including assault, robbery, and rape) that young unaccompanied migrants face when crossing Mexico overland on their way to the United States. Being of Honduran descent and having travelled to the region several times, I was galvanized. On top of a general urge to raise awareness about the plight of these young migrants, I wanted to better understand why they were so desperate to leave their country of origin under such risky conditions. Two

years later, this major research paper (MRP) has given me the opportunity to explore this question in more depth. The main objective of this work is therefore to provide a comprehensive overview of the factors causing or enabling the migration of unaccompanied children from the NTCA, based on a review of a wide range of sources in English and Spanish.

\section{Background}

\subsection{Who are "unaccompanied children"?}

The United Nations Convention on the Rights of the Child (1989, art. 1) defines a child as "a person below the age of 18 , unless the laws of a particular country set the legal age for adulthood younger." While the laws of Guatemala and El Salvador distinguish between children and adolescents (adolescence is reached at the age of 13 in Guatemala, and 12 in El Salvador), both of these countries, as well as Honduras, recognize individuals under the age of 18 to be minors (El Salvador, 2009, art. 3; Guatemala, 2003, art. 2; Honduras, 1996, art. 1). This MRP, 
therefore, takes the labels child and minor to be synonymous and applies them to any individual under the age of $18^{1}$.

More specifically, the United Nations High Commissioner for Refugees (henceforth, UNHCR) (1997) designates as unaccompanied a child "who is separated from both parents and is not being cared for by an adult who by law or custom has responsibility to do so" (p. 3). This definition includes both children who are journeying by themselves, as well as those, often referred to as separated children, who migrate with an adult other than a parent or habitual guardian, such as a family acquaintance, older sibling or more distant relative, or a smuggler (Bhabha, 2001, footnote 10, p. 284). This MRP will follow the preference of the recent Englishlanguage literature on youth migration from the NTCA, and will use the label unaccompanied to describe both categories of children traveling without their parents.

\subsection{Characteristics of the NTCA countries}

Figure 1 illustrates the geographic position of the three countries that form the NTCA.

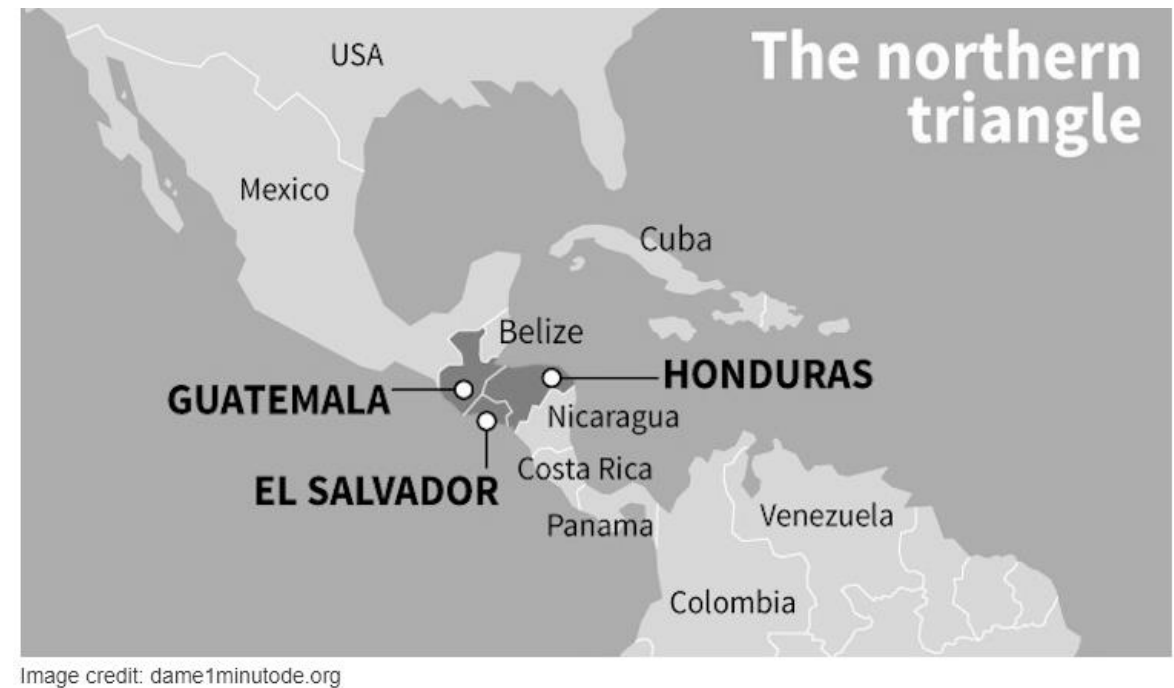

Figure 1. Map highlighting the position of the Northern Triangle within Central America

\footnotetext{
${ }^{1}$ I will also use the term youth interchangeably with child and minor.
} 
Aside from their physical contiguity, Guatemala, El Salvador, and Honduras share several common characteristics. First, all three countries have a relatively youthful population. According to the most recent figures from the Central Intelligence Agency World Factbook (2018), 46.15\%, 53.85\%, and 56.08\% of the populations of El Salvador, Honduras, and Guatemala, respectively, are under 25. Second, the region is known for its high homicide rates, which are reputed to be comparable to those found in war zones (Hiskey, Córdova, Orcés, \& Malone, 2016, p. 2). Per data from the United Nations Office on Drugs and Crime (henceforth, UNODC) (n. d.), the Honduran homicide rate peaked at 93.21 homicides per 100,000 people in 2011 (although it has since dropped to 63.75 in 2015); it was surpassed by the Salvadoran rate of 108.64 homicides per 100,000 people in 2015. The homicide rate in Guatemala was 31.21 per 100,000 people in 2014. Though moderate by NTCA standards, it, too, far exceeds the world average of 6.2 homicides per 100,000 people (UNODC, 2014, p. 21), as well as the threshold of 20 homicides per 100,000 people used to designate a country as having a high homicide rate (UNODC, 2014, p. 24).

Homicides particularly affect young people. In the early 2010s, the Salvadoran homicide rate of young men aged 15 to 29 was four times that of the world average for that age group (Consejo Nacional de Población [CONAPO, the National Population Council of Mexico], 2016, p. 58). In Honduras, in the same time period, the homicide rate for men aged 20 to 34 was three times the national figures, at 300 homicides per 100,000 (InSight Crime Honduras, n. d., cited in Musalo \& Lee, 2017, p. 159). In 2012, 48\% of female homicide victims in Honduras were under 30 (Rivera, Ruelas, Herrera Cuello, \& Flores Pinto, 2015, p. 113), and one quarter of female 
homicide victims in El Salvador were under 20 (Gaborit, Zetino Duarte, Orellana, \& Brioso, 2015, p. 193). ${ }^{2}$

The homicide rates are but one symptom of the generalized violence that reigns throughout the NTCA. Most of it is attributed to the expansion of youth gangs, the largest of which are Mara Salvatrucha (also known as MS-13) and Barrio (or Calle) 18 (Casa Alianza Honduras, Pastoral de Movilidad Humana, \& Catholic Relief Services, 2016, pp. 13-14). These gangs were formed in the United States in the 1980s and 1990s by young Salvadoran migrants who had fled the civil war in their country (Jones, 2017, p. 336; Torres, 2017, p. 12). Gang members were deported back to El Salvador in the late 1990s (Bacon, 2016). At that point, gangs took root in the country, multiplied, and spread to Guatemala and Honduras (Jaimez, 2017, p. 6). As of 2012, there were an estimated 22,000 gang members in Guatemala, 12,000 in Honduras, and 20,000 in El Salvador (UNODC, 2012, cited in Musalo \& Lee, 2017, p. 159). Further, drug trafficking organizations have moved their operations into the NTCA. South American drug producers have been pushed out of their traditional trade routes by the U.S. war on drugs and now use Honduras as their main exchange point with Mexican cartels (InSight Crime Honduras, n. d., cited in Musalo \& Lee, 2017, p. 156). The activities of drug traffickers and gangs are exacerbated by the free circulation of firearms throughout the region (Gatica López, 2016, p. 101; Machín Álvarez, 2015, p. 400; United Nations World Food Programme \& International Organization for Migration [WFP \& IOM], 2016, p. 25), a result both of the civil wars in El

\footnotetext{
${ }^{2}$ Gender-based violence is pervasive in the NTCA (Kids in Need of Defense \& Human Rights Center Fray Matías de Córdova [KIND \& HRCFMC], 2017, p. 22). The rates of femicide, that is, the killing of women and girls because of their gender (p. 4) are high in all three countries. Torres (2017) cited the 2012 Small Arms Survey according to which Honduras had the seventh highest rate of femicide in the world, with a rate of 7 homicides per 100,000 women, and Guatemala, the third, with 9.7 homicides per 100,000 women. El Salvador ranked first with 12 homicides per 100,000 women (p. 21).
} 
Salvador and Guatemala (that spanned from the 1970s to the early 1990s) and of arms trafficking between the Northern and Southern Hemispheres (Varela Huerta, 2015, pp. 23-24).

The three NTCA countries also share grim economic conditions: The unemployment rate is high, and those who do find work encounter below-minimum-wage salaries and extremely dangerous conditions in the informal economy (Casa Alianza Honduras et al., 2016, p. 28). The U. S. Government Accountability Office (henceforth, GAO) (2015) cited a 2011 World Bank study reporting that "more than $60 \%$ of Hondurans, more than $50 \%$ of Guatemalans, and $30 \%$ of Salvadorans live below the poverty line" (p. 2). More than one third of the employed population survives on less than US\$ 4 a day (Chishti \& Hipsman, 2015, p. 97; Rosenblum, 2015, p. 12). In addition, the region has been afflicted by drought since 2014 (WFP \& IOM, 2016, p. 9). This has decimated the livelihood of agricultural workers (Chishti \& Hipsman, 2016, "Why Are the Flows Continuing?" section; Tello, Castellon, Aguilar, \& Sawyer, 2017, p. 361) and caused food insecurity. According to the WFP and IOM (2016), 13\% of households in El Salvador, 25\% of households in Guatemala, and 36\% of households in Honduras are affected by food insecurity (p. 18), and nearly $50 \%$ of Guatemalans suffer from chronic undernutrition (p. 7).

Finally, to round out this bleak portrait of the NTCA, educational attainments levels are also low across the region. In the early 2010s, only $24.1 \%$ of Salvadorans, $28.1 \%$ of Guatemalans, and $23.9 \%$ of Hondurans had finished high school. What is more, about $50 \%$ of the population of the region had only completed elementary school (World Bank, 2016, cited in CONAPO, 2016, p. 52). Poor economic prospects and restricted educational opportunities go hand in hand: More than $25 \%$ of the population of Honduras and El Salvador aged 15 to 29 is neither working nor pursuing higher education (De Hoyos, Rogers \& Székely, 2016, cited in Tello et al., 2017, p. 361). 
Having defined the population of interest and described the main relevant characteristics of the countries of origin, I will now provide an overview of the trends in the migration of unaccompanied children since 2011.

\section{Unaccompanied child migrants from the NTCA}

Because unaccompanied children typically migrate through undocumented channels, it is very difficult to obtain statistics about their migration (Nichols, Umana, Britton, Farias, Lavalley, \& Hall-Clifford, 2017, pp. 1972-1973). The figures on unaccompanied children are in fact derived indirectly, through numbers of apprehensions in, and deportations from, the countries of destination and transit. These statistics present a number of limitations: They do not account for the children who went undetected by immigration authorities (Machín Álvarez, 2015, p. 393), nor those who left their country but never made it to their destination (Gaborit et al. 2015, p. 197). Moreover, some analysts argue that apprehension data may better reflect the efficacy of border patrol activities than the actual number of child migrants (Nichols et al., 2017, p. 1972). In spite of these caveats, the use of these statistics, and in particular the figures for apprehensions by the U.S. Customs and Border Protection (henceforth, USCBP), is nevertheless standard when discussing the migration of unaccompanied children. In this section, as in the rest of the MRP, apprehension data will therefore be used as a proxy, albeit imperfect, for migration rates. $^{3}$

Migration of unaccompanied children from the NTCA is not a new phenomenon (see Chávez and Menjívar's [2010] survey of the studies on the topic published prior to 2010, as well as Enrique's Journey, journalist Sonia Nazario's non-fiction account of a Honduran teenager's

\footnotetext{
${ }^{3}$ I will discuss U.S., rather than Mexican, apprehension statistics, because they are used in the studies presented in the findings in Chapter 3.
} 
repeated attempts to reach the United States via Mexico, first published in 2006). Yet, since 2011, a number of indicators suggest that this flow is accelerating and that its nature is changing.

First, the absolute numbers, given in Table 1, of unaccompanied children claiming to be from the NTCA have been rising.

Table 1. U.S. apprehensions of unaccompanied children, 2011-2018, per self-reported country of origin

\begin{tabular}{|l|l|l|l|l|l|l|l|l|}
\hline $\begin{array}{l}\text { Self-reported } \\
\text { country of } \\
\text { origin }\end{array}$ & $\mathbf{2 0 1 1}$ & $\mathbf{2 0 1 2}$ & $\mathbf{2 0 1 3}$ & $\mathbf{2 0 1 4}$ & $\mathbf{2 0 1 5}$ & $\mathbf{2 0 1 6}$ & $\mathbf{2 0 1 7}$ & $\mathbf{2 0 1 8}$ \\
\hline EI Salvador & 1,394 & 3,314 & 5,990 & 16,404 & 9,389 & 17,512 & 9,143 & 4,035 \\
\hline Guatemala & 1,565 & 3,835 & 8,068 & 17,057 & 13,589 & 18,913 & 14,827 & 24,720 \\
\hline Honduras & 974 & 2,997 & 6,747 & 18,244 & 5,409 & 10,468 & 7,784 & 9,525 \\
\hline Mexico & 11,768 & 13,974 & 17,240 & 15,634 & 11,012 & 11,926 & 8,877 & 10,035 \\
\hline Total & 16,056 & 24,481 & 38,759 & 68,541 & 39,970 & 59,692 & 41,435 & 48,558 \\
\hline
\end{tabular}

Sources: CONAPO (2016, p. 23) for 2011-2012; USCBP (2017) for 2013-2017; USCBP (2018) for 2018.

*Annualized from year-to-date figures. USCBP reports data by fiscal year, from October 1 to September 30 of the following calendar year.

As depicted in Figure 2, the number of children from each of the three NTCA countries started to rise in 2011, reaching a peak in 2014 (which was commonly referred to in the press as a "surge" [e.g., Musalo \& Lee, 2017]). The numbers have fluctuated since then, but they are without exception higher now than in 2011. 


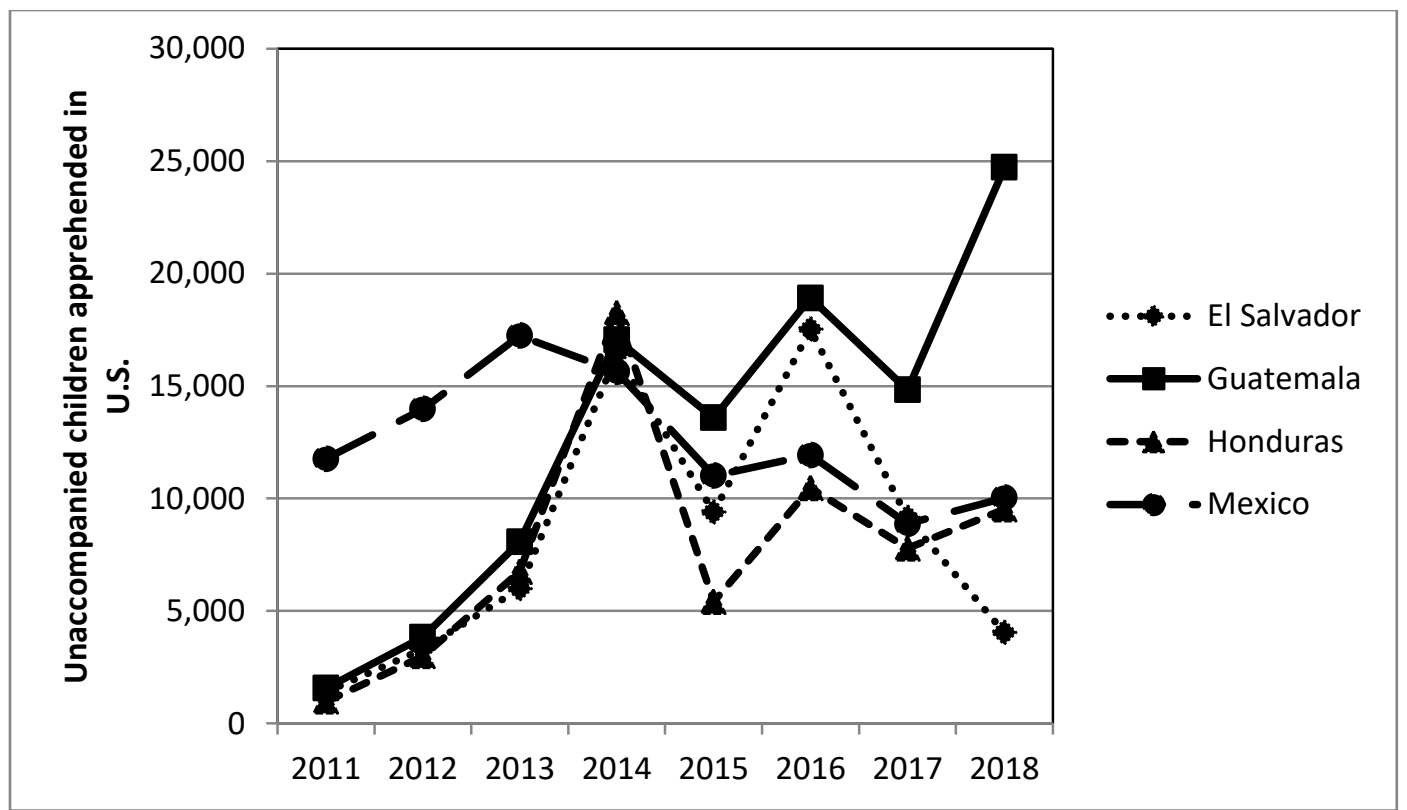

Figure 2. Apprehensions of unaccompanied children in the United States, 2011-2018

Second, most of the growth in the overall numbers of unaccompanied children apprehended in the United States can specifically be attributed to the increase in migrants from the NTCA (Lorenzen, 2016, p. 188). Based on the figures in Table 1, in 2011, 73.3\% of unaccompanied children were Mexican, a proportion that has dropped to $20.7 \%$ partway through 2018. In parallel, the proportion of unaccompanied children from the NTCA has shot up, from $24.5 \%$ in 2011 to $78.8 \%$ partway through 2018.

Third, as observed by Jones (2017), the proportion of unaccompanied children in the general flow of migrants from the NTCA has grown: In 2011, unaccompanied children represented 5\% of all migrants from the NTCA apprehended by USCBP; in 2014, their proportion grew to $20 \%$ of all apprehended migrants from the region (p. 334).

Fourth, the basic demographic characteristics of unaccompanied children from the NTCA have been changing. Based on USCBP data, the majority of apprehended youth are adolescent males aged 16 or 17 (Jones, 2017, p. 334). However, the number of children under 12 and of girl migrants has increased in the last few years (Lorenzen, 2016, p. 197; Rivera et al., 2015, p. 117). 
Chishti and Hipsman (2015) report that the proportion of unaccompanied girls apprehended in the United States had risen to 23\% in 2012 from 15\% in the early 1990s. After 2012, it continued to increase gradually, reaching $27 \%$ in 2013, and 34\% in 2014 (p. 97). Likewise, the proportion of apprehended children aged 0 to 11 grew between 2011 and 2016 for all three nationalities, from $11.9 \%$ to $17.2 \%$ for Guatemalans, from $9.8 \%$ to $23.8 \%$ for Hondurans, and from $12.6 \%$ to $22.4 \%$ for Salvadorans (Lorenzen, 2016, p. 197). ${ }^{4}$

The U.S. government responded to the 2014 "surge" in apprehensions by introducing various deterrence measures, including increased securitization of the U.S.-Mexico border and awareness campaigns warning potential migrants of the dangers of the journey, as well as investment to stimulate economic growth (Rosenblum \& Ball, 2016, p. 2) and funding for programs for at-risk youth in the NTCA countries (Roth \& Hartnett, 2018). The measures initially seemed effective, as the numbers of unaccompanied children dropped abruptly in 2015, as depicted in Figure 2, registering a 45.08\% drop (Cajina \& Orozco, 2016, p. 11). However, the numbers began to rise again in late 2015, and remained high in 2016 (Chishti \& Hipsman, 2016). Despite another drop in 2017, the figures for 2018 so far suggest yet another spike: According to USCBP (2018), the number of unaccompanied children apprehended in May 2018 represented a 329\% increase over May 2017.

Moreover, U.S. apprehension figures tell but one part of the story. Indeed, while the number of apprehended unaccompanied children from NTCA countries declined in 2015 in the United States, it increased that same year in Mexico (Cajina \& Orozco, 2016, p. 11), following the implementation of the Programa Frontera Sur (Southern Border Program). Financed by the United States, this program is intended to prevent the entry of undocumented migrants to the United States by securitizing the border between Guatemala and Mexico (Cajina \& Orozco,

\footnotetext{
${ }^{4}$ These broad trends are also reflected in Mexican apprehension data (CONAPO, 2016).
} 
2016, pp. 11-12; Hiskey et al., 2016, p. 4; Lorenzen, 2016, p. 183; Rosenblum \& Ball, 2016, p. 2). The number of unaccompanied children apprehended in Mexico, over $90 \%$ of whom came from the NTCA, rose from 23,096 in 2014 to 38,514 in 2015 (Lorenzen, 2016, p. 191). Mexico's share of the combined numbers of apprehensions of migrants from the NTCA in the United States and Mexico grew from 30\% in 2014 to 55\% in 2015 (Chishti \& Hipsman, 2016, “A Look at the Trends" section).

In addition to the overall rise in apprehensions in the United States between 2011 and $2018^{5}$ and the increased apprehensions in Mexico over the same time period, there is also evidence that unaccompanied children, like their adult counterparts, are making their way to other neighbouring countries, such as Belize, Costa Rica, and Panama (UNHCR, 2014a, p. 15). Taken together, the high apprehension figures and multiple countries of destination indicate that the migration of unaccompanied children from the NTCA is a persistent and regional phenomenon.

\section{Debates about the causes of the migration of unaccompanied children from the NTCA}

Writing in the years before the numbers of apprehensions swelled, Chávez and Menjívar (2010) concluded that economic factors and family reunification were the primary drivers of the migration of unaccompanied children from the NTCA (p. 84), with gang violence still representing a relatively marginal, though growing, phenomenon at the time (p. 89). Are these same factors at the core of the current, much larger, flow? At the height of the 2014 "surge" in the United States, commentators argued as to whether push factors in the countries of origin,

\footnotetext{
${ }^{5}$ Nichols et al. (2017) reported that NGO staff in Guatemala attributed the increase in the number of apprehensions to fact that that children were being told to turn themselves in to USCBP, rather than evade detection, once they arrived in the United States, possibly due to a misunderstanding of U.S. immigration policy (p. 1967). In fact, several of the participants in that study disputed the claims that the number of children leaving Guatemala on their own had increased.
} 
such as the violence and lack of economic opportunities described in the first section of this chapter, or pull factors, such as the perceived leniency of U.S. immigration policy toward children, were responsible for this migration (Preston, 2014). Similar debates have appeared in the academic and grey literature, with many analysts affirming that there is no consensus on the primacy of factors such as violence, economic conditions, or family reunification as for the migration flow (Cajina \& Orozco, 2016, p. 4; Chishti \& Hipsman, 2014, "Why Is This Happening?” section; 2015, pp. 96-97; Jones, 2017, p. 334).

Underlying the debates about the relative importance of violence and economic factors are traditional models of migration that assume a well-defined distinction between forced and voluntary migration (see Richmond, 1993, p. 7). Conventionally, forced migration is considered synonymous with seeking protection from "persecution, violence, war, severe human rights violations, and other threatening situations" (Lorenzen, 2017, p. 745). Voluntary migration, for its part, has been conflated with migration for economic reasons. A growing body of research, however, disputes the forced/voluntary dichotomy (e.g., Betts, 2013; Huijsmans, 2012, p. 30; Lorenzen, 2017; Orgocka, 2012, p. 5). Indeed, forced and voluntary migrants may use the same migratory channels (Betts, 2013, p. 15), and individuals may have multiple reasons for migrating, some of which would qualify them as forced migrants, and others, as voluntary migrants (Lorenzen, 2017, pp. 745-746). Further, poor economic conditions often co-occur with threats to physical security in a single country. As Castles (2007) observes, "[c]ountries with weak economies, increasing inequality and widespread impoverishment tend also to have tyrannical rulers, weak state apparatuses, and high levels of violence and human rights violations" (p. 26). Economic conditions and violence may therefore be closely entwined. Moreover, Betts (2013) contends that migration for economic reasons may sometimes be close to 
the forced end of the migration spectrum: Economic conditions in the country of origin may be so dismal as to deprive people of subsistence (p. 17), which Betts considers to be a fundamental right, that is, a "right without which no other right can be enjoyed" (p. 23). Migrating to improve one's socioeconomic conditions may, therefore, sometimes be as much of a matter of survival as fleeing violence is.

The question of migrant agency and choice is inherently built into the forced/voluntary dichotomy (Richmond, 1993, p. 9). It takes on a different dimension in the case of unaccompanied child migrants, however. In the Western world, children are often construed as having no agency and as being wholly dependent on their parents (Meloni, Rousseau, Montgomery, \& Measham, 2014, p. 306). In the context of migration, they are inevitably construed as "bullet children" sent ahead to the destination country to facilitate the entry of the rest of their family as economic migrants (Bryan \& Denov, 2011, p. 249). Much of the literature on the migration of unaccompanied children, however, advocates for the recognition of children as social actors in their own right (Chavez \& Menjivar, 2010, p. 72) and makes the case that children sometimes decide to migrate of their own volition in order to escape precarious conditions (O’Higgins 2012, p. 82; Orgocka, 2012, p. 3).

Summing up, the debates about the drivers of the migration of unaccompanied children from the NTCA rest on two apparent dichotomies: the first between push and pull factors, and the second between economic migration and migration motivated by violence, which are widely understood to be synonymous with voluntary and forced migration, respectively.

\section{Research question}

Based on this preliminary review of the literature, the core research question of the MRP is, "What are the factors driving the migration of unaccompanied children from the NTCA?" 
Two subsidiary research questions further specify the core question: "Are unaccompanied children from the NTCA motivated chiefly by push or pull factors?" and "Are unaccompanied children from the NTCA primarily migrating for economic reasons, to flee from violence, or because of a combination of the two factors?" Following Castles (2013), I take the word driver to refer to factors that compel people to migrate (i.e., causes) as well as those that facilitate their migration (i.e., enabling factors) (p. 124).

The MRP sets out to answer these research questions by applying a grounded theory approach (e.g., Corbin \& Strauss, 2015) to a scoping review (e.g., Daudt, van Mossel, \& Scott, 2013) of the literature that has dealt with this topic. Based on the data yielded by the scoping study, I conclude that unaccompanied children are primarily motivated by the violence and economic conditions in their countries of origin (i.e., push factors), but that their migration may be enabled by family reunification and perceptions of ease of entry to the destination country (i.e., pull factors). Further, I will demonstrate that economic factors and violence are so intertwined as to be virtually impossible to tease apart, and together conspire to deprive children of basic rights.

\section{MRP structure}

The rest of this MRP will be divided in four chapters. Chapter 2 will present the methodology I used to conduct my scoping review. Chapter 3 will present the major claims about the drivers of the migration of unaccompanied children from the NTCA, as put forward in the sources reviewed. Chapter 4 will evaluate these claims in light of the two subsidiary research questions. Finally, Chapter 5 will summarize the findings of the MRP before identifying gaps in the existing literature and recommending directions for future research. 


\section{CHAPTER 2. METHODOLOGY.}

This chapter describes the methods I used to answer my research questions. In order to get to the bottom of the question about the drivers of the migration of unaccompanied children from the NTCA, I applied a grounded theory approach to analyze data collected from a range of documentary sources. I will begin by providing an overview of grounded theory and of the methodology I used to carry out my scoping review before describing the details of my data collection and data analysis procedures.

\section{Grounded theory}

The goal of grounded theory is to build a data-driven explanation, or theory, of a particular phenomenon (McMillan \& Wergin, 2006, p. 6). Rather than imposing a previously developed theoretical framework on the data collected, grounded theory allows the data to dictate the shape of the emerging theory. It therefore requires the analyst to set aside prior assumptions and preconceptions about the phenomenon (Creswell \& Poth, 2018, p. 88) and to collect a wide range of evidence in order to elaborate a complete, or "saturated," account (Creswell \& Poth, 2018, p. 87). Grounded theory thus begins with "few foreshadowed questions" (McMillan \& Wergin, 2006, p. 6) or hypotheses. Rather than testing hypotheses, therefore, a study based in grounded theory will generate hypotheses that can be tested in future research.

As reported in Chapter 1, the literature on unaccompanied children from the NTCA states repeatedly that there is no agreement about the drivers motivating or promoting their migration, or about the relative weight of these factors. A grounded theory approach therefore seems like a fruitful avenue for making sense of the range of claims about this phenomenon.

Grounded theories must be based on large amounts of data in order to be comprehensive (Creswell \& Poth, 2018, p. 87). In this MRP, I will use the existing literature, identified and 
analyzed using a scoping review methodology, as a stand-in for a large empirical data set. The next section will introduce the fundamental principles of a scoping review methodology.

\section{Scoping review methodology}

According to Daudt et al. (2013), "[s]coping studies aim to map the literature on a particular topic or research area and provide an opportunity to identify key concepts; gaps in the research; and types and sources of evidence to inform practice, policymaking, and research" (p. 8). In order to do so, scoping reviews begin with broad, exploratory research questions and strive to sample a comprehensive array of sources (Gerstein Science Information Centre, n. d.). Thus, this methodology coincides with the tenets of grounded theory.

I conducted a scoping review of materials written in English and Spanish that described and analyzed the factors driving the increased migration of unaccompanied children from the NTCA. The aim of my scoping review was to identify and analyze sources that presented a wide range of claims on the drivers of this migration flow and provided varied types of evidence to support those claims. The sections that follow describe the steps prescribed for a scoping review (based on Daudt et al., 2013), including sampling, data collection, and data analysis.

\section{Sampling}

\subsection{Identifying relevant studies}

The first step was to compile an exhaustive list of sources on the topic of the migration of unaccompanied children from the NTCA. The sources identified were in either English or Spanish (a language I read fluently) in order to represent not only the perspective of the United States, the main destination country, but also that of other receiving countries, such as Mexico, and, to the extent possible, that of the sending countries. 
The first tool I used to identify potentially relevant studies was the Ryerson University Library and Archives (RULA) catalogue. I limited the timeframe of the study to sources published in or after 2010 in order to not only match the period in which the number of unaccompanied children migrating from the NTCA increased, but also to include all the relevant sources that have been published since Chávez and Menjívar (2010), which is, to my knowledge, the only published wide-scale survey of the literature on this topic. I searched for books, book chapters, dissertations or theses, scholarly articles, newspaper or magazine articles, and reports (including working papers series).

For the sake of exhaustiveness, I performed successive searches using the Englishlanguage terms and operators listed in Table 2, in order to capture the gamut of synonyms used to refer to unaccompanied children, and to locate sources that dealt with all three countries of origin as well as those that focused on a single one. I searched for sources within the following disciplines: economics, education, geography, government, international relations, law, political science, public health, social sciences, social welfare \& social work, sociology \& social history.

Table 2. Summary of English-language search queries in RULA catalogue

\begin{tabular}{|l|l|}
\hline & Terms, operators, and wildcards searched \\
\hline Population & (unaccompanied OR separated) AND (child* OR minor*) \\
\hline Region & "central america" OR guatemala OR “el salvador" OR honduras \\
\hline
\end{tabular}

I used complementary methods to supplement source types that were underrepresented in the RULA catalogue (such as NGO and policy reports): I consulted Google Scholar to locate the scholarly articles that cited Chávez and Menjívar's (2010) paper; I scanned the bibliography of

\footnotetext{
${ }^{6}$ Note that I did not include search terms such as "cause", "motive", or "driver", in order to simplify the search query. The initial round of searches therefore brought up sources that did not necessarily focus solely on the drivers of the migration flow.
} 
particularly useful sources; and I inspected the "Related Articles" sidebar when I downloaded an article from a scholarly journal website.

Slightly different strategies were required to locate potentially relevant sources in Spanish. I started by searching the RULA database using similar parameters as for Englishlanguage sources (in terms of disciplines and time period included). Table 3 shows the search terms used.

Table 3. Summary of Spanish-language search queries in RULA catalogue

\begin{tabular}{|l|l|}
\hline & Terms searched \\
\hline Population & (niños OR menores) AND ("no acompañados" OR "sin companía") \\
\hline Region & "centroamérica" OR guatemala OR "el salvador" OR honduras \\
\hline
\end{tabular}

These searches provided very few results, given the limited number of holdings in Spanish in the RULA catalogue. I therefore had to rely more heavily on Google Scholar (using similar search terms to those listed in Table 3) and on bibliography mining. As a result, and because of limited access to Spanish resources due to my geographic location, I am making no claims to comprehensiveness for the Spanish-language resources.

\subsection{Inclusion and exclusion criteria for study selection}

The next step was to narrow down the list of 244 sources yielded by the initial searches to a sample that would address my research questions. My guiding principle was to include

\footnotetext{
${ }^{7}$ The Spanish search terms refer to the following keywords that are used in the literature on unaccompanied children: niños/menores no acompañados ("unaccompanied children/minors"), niños/menores sin companía ("children/minors without company"). This is not an exhaustive inventory of the synonyms used to refer to this population.
} 
materials that contained original data or an original analysis of the drivers of migration of unaccompanied children from the NTCA. ${ }^{8}$

I excluded materials that primarily described the migration journey or focussed on the experiences of unaccompanied children in the destination countries, including integration and the navigation of the asylum process, as well as sources on deportation and reintegration in the country of origin. I did, however, include sources that collected data from migrant children while they were in transit, once they had arrived in the destination country, while they awaited deportation, or even after they had been "repatriated" to their country of origin, as long as the research questions or major findings included the causes motivating the migration flow or the factors enabling it.

I applied a theoretical sampling method to the long-list of materials dealing substantively with the drivers of migration and selected sources "based on new insights they may provide" (Neuman, 2006, p. 224). I started by reading materials that provided a solid overview of the main categories of drivers of migration, and then built up the sample by adding sources that provided additional details about specific drivers. $^{9}$

I stopped adding sources when the sample had reached saturation, and the remaining sources no longer provided novel data. The final sample included 58 sources, which will be described in the next subsection.

\footnotetext{
${ }^{8}$ Some of the studies included in the final sample consider the factors that led to the migration of unaccompanied children from Mexico as well as the NTCA (e.g., Donato \& Sisk, 2015; Schmidt, 2017a; UNHCR, 2014a). Given the focus of this MRP, I only took into account the claims relevant to children from the NTCA.

${ }^{9}$ An initial examination of newspaper articles revealed that few of them contained any substantive claims that were not expressed elsewhere in the literature. I therefore decided to not systematically consider them for inclusion in my database, but following theoretical sampling principles, I did select some that covered an aspect of the drivers of migration that was not well represented in other sources.
} 


\subsection{Description of sample}

Of the 58 sources in the database, 37 are in English, and 21 are in Spanish. (The appendix provides the full list of sources sampled and a summary of their main characteristics.) Table 4 illustrates the distribution of sources by language and type. Scholarly articles represent the main category of item among the English-language sources (15), followed by policy reports (10). Among the Spanish sources, scholarly articles are also the largest category of source type (8), followed very closely by NGO reports (7).

Table 4. Distribution of database items by language and type

\begin{tabular}{|l|l|l|l|}
\hline Type of source & English & Spanish & Total \\
\hline Scholarly article & 15 & 8 & 23 \\
\hline NGO report & 5 & 7 & 12 \\
\hline Policy report & 10 & 0 & 10 \\
\hline Newspaper/magazine article & 5 & 4 & 9 \\
\hline Thesis & 2 & 2 & 4 \\
\hline Total & 37 & 21 & 58 \\
\hline
\end{tabular}

The sources selected include both empirical studies and reviews of other studies. As shown in Table 5, among the empirical studies, a total of 25 items across both languages presented data collected from migrant children (primarily through surveys, interviews, or narrative techniques), 11 reported data from other stakeholders (including staff members of NGOs that work with youth, government officials, parents, and adults from the larger population in the countries of origin or of destination), and 6 examined correlative evidence of relationships between various indicators and the number of unaccompanied children apprehended in the United States. ${ }^{10}$

\footnotetext{
${ }^{10}$ Some items in the database presented evidence of more than one type; consequently, the numbers in Table 5 add up to more than 58 .
} 
Table 5. Distribution of database items by language and source of evidence

\begin{tabular}{|l|l|l|l|l|}
\hline Source of evidence & English & Spanish & Total \\
\hline \multirow{4}{*}{ Empirical } & Unaccompanied children & 14 & 11 & 25 \\
\cline { 2 - 5 } & Other stakeholders & 9 & 2 & 11 \\
\cline { 2 - 5 } & Correlative evidence & 6 & 0 & 6 \\
\hline Analysis of findings of other studies & 12 & 9 & 21 \\
\hline
\end{tabular}

Different data collection and analysis methods yield different results and answer different research questions. Data collected from children has the advantage of shedding light on the actual experiences of the population of interest. Data collected from other stakeholders may provide insight into broader dynamics. Correlative evidence ${ }^{11}$ indicates the existence or absence of a relationship between specific indicators of conditions in the country of origin or destination and the rate of migration of unaccompanied children. While correlative evidence does not establish a causal link between factors (Kranzler, 2011, p. 87), it may reveal connections that could not be observed by individuals (Neuman \& Robson, 2012, p. 102). ${ }^{12}$ The examination of these three types of data allows for triangulation: Where all three coincide as to the importance of a factor, we can be reasonably certain of the credibility of the findings (McMillan \& Wergin, 2006, p. 96).

\section{Data extraction and analysis}

After all the relevant materials have been gathered, the next step in a scoping review is data extraction and analysis. Even though my sample is composed of both quantitative and qualitative materials, I adopted a qualitative strategy to analyze them all: I coded each source as

\footnotetext{
${ }^{11}$ I am using the expression "correlative evidence" as a loose cover term for any statistical analysis that tests a relationship between factors. It therefore covers not only correlations, but also regression analyses. ${ }^{12}$ Furthermore, the absence of a statistically significant correlation may not signal the actual absence of a relationship between two factors, but may rather be an artefact of the choice of variables and their operationalization.
} 
it were a transcript of an interview with a key informant. Following grounded theory principles, I implemented a three-stage coding scheme in order to categorize the key concepts and themes in the materials, as well as the links between them (Creswell \& Poth, 2018, pp. 84-85). In the first stage, open coding, I classified relevant passages from each source into several narrow categories of information (that I will refer to as "subthemes" in Chapter 3). At the second stage, axial coding, I combined the open codes into core codes representing the major drivers of migration. In the third stage, selective coding, I determined the relationships between major drivers in order to answer the research questions. I used NVivo 11 Plus software (QSR International, 2015) for open and axial coding (I aggregated the "child nodes" created during open coding into "parent nodes" at the axial coding stage). Chapter 3 will present the findings identified through open and axial coding. Chapter 4 will present the results of selective coding.

\section{Limitations}

The study presented in this MRP presents three main methodological limitations. First, because I am relying exclusively on prior work by other researchers, I do not have access to raw data, and the conclusions of my study will be based on my interpretation of another researcher's analysis. Second, as mentioned earlier, the Spanish-language sources do not represent a comprehensive sample of the sources on this topic. Third, I impressionistically determined when my English-language sample had reached saturation, and therefore have no external corroboration of the comprehensiveness of this subsample. 


\section{CHAPTER 3. FINDINGS.}

This chapter reports the main drivers of the migration of unaccompanied children from the NTCA. Before I begin, a terminological note is warranted. As pointed out in Chapter 1, driver is a broad cover term that encompasses all of the factors that are involved in a migration "decision calculus" - to borrow the turn of phrase from Hiskey et al. (2016, p. 2) - namely, causes (underlying and immediate) as well as enabling factors. Many of the sources consulted do not distinguish between causes and enabling factors, and designate all drivers as "causes" or "reasons". In this chapter, therefore, I will make no attempt to categorize the drivers (I will use cause, reason, motive, and driver interchangeably at this stage). The distinction between causes and enabling factors is, however, analytically important, and will be developed in the discussion in Chapter 4.

A first important finding is that, contrary to the oft-repeated claims of a lack of consensus, there is in fact remarkable consistency in the main drivers cited. During axial coding, I identified four core themes corresponding to the major drivers of migration. Three of these, already named in Chapter 1, are mentioned by virtually all the studies: All 58 sources mention factors related to violence; 56 sources cite a cluster of factors related to the socioeconomic conditions prevailing in the countries of origin; and 52 sources invoke factors related to the family of the migrant children. A fourth category receives frequent, though less persistent, coverage: the role of the perception of ease of entry into the United States due to lenient immigration policies, which is mentioned by 25 sources.

The four major drivers of migration were fleshed out by the subthemes that had been identified during open coding. The next sections present a discussion of these drivers and their subthemes organized according to three main types of evidence: data collected from children, 
evidence from other stakeholders, and correlative evidence suggesting statistical relationships between migration rates and conditions in the country of origin or of destination. Open coding also revealed underlying conditions that determine the impact of some of the drivers and uncovered the intersection between drivers and certain demographic characteristics, as discussed at the end of this chapter. ${ }^{13}$

\section{Violence as a driver of migration}

Open coding revealed six subthemes related to violence that are reflected in some or all types of evidence: generalized violence in the NTCA region, gang violence, sexual and genderbased violence, domestic violence, homicide rates, and a lack of state protection.

\subsection{Evidence from children}

The studies that collected data from children report that their participants cited numerous forms of violence as an immediate trigger for departure. For example, a 2014 UNHCR study among 404 unaccompanied minors apprehended in the United States found that $48 \%$ of them cited violence in their community (UNHCR, 2014a, pp. 25, 26). ${ }^{14}$ That same year, the UNHCR office in Mexico carried out a similar study, in which $48.6 \%$ of the 272 children interviewed invoked some type of physical violence (UNHCR, 2014b, p. 43). Some studies reported much higher proportions of child migrants who named violence- $-77 \%$ of the 151 participants in a study by the Women's Refugee Commission (henceforth, WRC) (2012, p. 7) stated that they left their country because of violence, while others noted a much lower incidence—only 5 of the 77

\footnotetext{
${ }^{13}$ Additional drivers mentioned infrequently include a thirst for adventure and travel (Khashu, 2010, pp. 21-22), displacement due to mega development projects (Acuña González, 2016, p. 58; Varela Huerta, 2015, p. 24), medical reasons (Acuña González, 2016, p. 58; UNHCR, 2014b, p. 41), and human trafficking (Ceriani Cernadas, 2012, p. 10; KIND \& HRCFMC, 2017, p. 20; Suárez Orozco, 2015, p. 5).

${ }^{14}$ This study also included unaccompanied children from Mexico, and this figure reflects their answers as well as those of children who had migrated from the NTCA.
} 
participants interviewed by Khashu (2010) claimed to have left because of some kind of violence (p. 22). ${ }^{15}$

The most widely cited type of violent threat comes from the streets gangs first introduced in Chapter 1. Indeed, out of 125 children interviewed by the UNHCR (2014a) in the United States, 108 mentioned gangs (p. 26). The children cited multiple types of aggressions by gang members, who are often their same-age peers (Schmidt, 2017a, p. 60): violent initiations (Suárez-Orozco, 2015, p. 18); attempts to forcibly recruit children as young as 6 years old (Rivera et al., 2015, p. 114), with threats of reprisal against the child or their relatives if they refused to join (Becker Herbst, Sabet, Swanson, Suarez, Marques, Ameen, \& Aldarondo, 2018, p. 253; Cao, 2017, p. 16; Casa Alianza Honduras et al., 2016, p. 44; Martín, 2014; Jaimez, 2017, p. 21; Kennedy, 2014, p. 2; Robles, 2014; Tello et al., 2017, pp. 364-365; WRC, 2012, p. 5); extortion, in particular of children who have a parent living in the United States (Kids in Need of Defense \& Human Rights Center Fray Matías de Córdova [KIND \& HRCFMC], 2017, p. 17; Lorenzen, 2017, p. 758); attacks against children who live in a rival gang's territory (Kennedy, 2014, p. 2; UNHCR, 2014a, p. 26); the murder of a relative (Cao, 2017, p. 16; Jaimez, 2017, pp. 21, 22, 25; Tello et al., 2017, p. 364, 365; UNHCR, 2014a, p. 39); and physical assault (Becker Herbst et al. 2018, p. 253-254; Kennedy, 2014, p. 2; UNHCR, 2014a, p. 32, 36). Children who had previously been affiliated with gangs decided to flee after refusing to commit an assault or a murder ("Sin nada, me tiré a la calle" ["With nothing to lose, I went to live on the street"], 2014; UNHCR, 2014b, p.48). Gangs also exert more subtle forms of harrassment. For

\footnotetext{
${ }^{15}$ It should be noted that Khashu collected her data in 2007-2008, before the numbers of unaccompanied children from the NTCA started to grow. The role of violence as a driver of migration appears to have strengthened in the last decade. The UNHCR (2014b) study conducted in Mexico cited a survey of Central American migrant children conducted between 2006 and 2008, in which only 13\% of participants indicated they were fleeing to seek protection from societal or domestic violence (p. 23). In contrast, in the 2014 study, $48.6 \%$ of respondents were fleeing societal violence.
} 
example, recruitment attempts affect children's ability to attend school. It is often their classmates who try to recruit or extort them, while teachers and other authorities look on helplessly (e.g. Jaime, 2017, p. 29; Kennedy, 2014, p. 2; UNHCR, 2014a, p. 27).

Many children stated they were fleeing from an atmosphere of generalized terror perpetrated by gangs. WRC (2012) cites the case of a Honduran girl who was afraid to take public transit due to reports that gangs would set fire to buses full of passengers if the driver refused to pay an extortion fee (p. 7). A few children, however, invoked specific instances of violence or threats against them or a relative as the immediate trigger for their migration (for example, 109 of the 322 Salvadoran deportees interviewed by Kennedy [2014] had first-hand experience of gang recruitment [p. 2]). The quote below from a 17-year-old Honduran girl expresses multiple types of attacks from gangs:

The gangs in Honduras threatened me, and because of the gangs, my 17-year-old brother died three years ago... The gangs also threatened to kill me if I didn't join them. (quoted in Cao, 2017, p. 16)

Girls face specific types of threats from gangs. While they are also vulnerable to recruitment and extortion, they mainly fear being raped or kidnapped by gang members (Kennedy, 2014, p. 2; KIND \& HRCFMC, 2017). Girl migrants, and to a lesser extent boys, also cited sexual violence at the hands of relatives and strangers as a trigger for their migration (Schmidt, 2017b, p. 54; UNHCR, 2014a, p. 29).

Yet another type of violence was named by a small, but non-negligible, number of children: domestic violence (Cao, 2017, p. 4, 18). In the UNHCR (2014a) study conducted in the United States, $21 \%$ of Guatemalans (p. 46) and $24 \%$ of Hondurans (p. 36) mentioned being survivors of domestic violence. Some teenage girls in other studies also reported having migrated due to intimate partner violence (UNHCR, 2014b, p. 20) 


\subsection{Evidence from other stakeholders}

Interviews with staff members of NGOs who work with youth in Guatemala indicated that parents feared that their children would fall victim to physical violence, and therefore encouraged them to migrate (Nichols et al., 2017, p. 1977). GAO (2015) surveyed U.S. government officials posted in the NTCA countries who confirmed the importance of this factor

(p. 4), as did lawyers representing unaccompanied youth at their immigration hearings (Cao, 2017, p. 12). KIND and HRCFMC (2017) affirmed that government and civil society actors corroborated the widespread sexual and gender-based violence against children in the NTCA (p. 10). Finally, Orozco and Yansura (2014) reported the results of a survey conducted among adult immigrants from the NTCA living in the United States. Thirty-six percent of their respondents cited violence as a cause for the migration of unaccompanied children (p. 15). These findings indicate that popular discourse in the region links child migration to violence.

\subsection{Correlative evidence}

In this section, I review sources that test the relationship between the number of apprehensions in the United States and the rates of homicide per 100,000 people in the communities of origin of unaccompanied children. Table 6 summarizes the relevant results.

Table 6. Correlative evidence of a link between homicide rates and migration

\begin{tabular}{|l|l|}
\hline Homicide indicator & $\begin{array}{l}\text { Statistically significant relationship with } \\
\text { the number of apprehensions of } \\
\text { unaccompanied children? }\end{array}$ \\
\hline $\begin{array}{l}\text { Homicide rate in municipality of origin in 2013 } \\
\text { (Orozco \& Yansura, 2014) }\end{array}$ & Yes \\
\hline $\begin{array}{l}\text { Homicide rate in municipalities of origin, } \\
\text { 2011-2016 (Clemens, 2017) }\end{array}$ & Yes \\
\hline $\begin{array}{l}\text { Homicide rate in department of origin in 2014, } \\
\text { Honduras only (Jones, 2017) }\end{array}$ & Yes \\
\hline $\begin{array}{l}\text { Homicide rate in countries of origin, 2008- } \\
\text { 2014 (Jones, 2017) }\end{array}$ & No \\
\hline
\end{tabular}


Orozco \& Yansura (2014) found that municipalities with high numbers of child migrants in 2014 also had a high number of homicides as a share of the national total (but the analysis does not control for the fact that the municipalities with a high number of homicides have a correspondingly higher population) (pp. 7-8). Clemens (2017) replicated this finding over time, using apprehension data collected between 2011 and 2016 (pp. 10-15). Similarly, Jones (2017) reported a statistically significant positive correlation between numbers of child apprehensions and departmental ${ }^{16}$ homicide rates in Honduras (p. 351). In contrast, another of Jones's (2017) findings suggests that, between 2008 and 2014, the national homicide rate in the three NTCA countries was not related to the migration rates of unaccompanied children (p. 349): The homicide rates declined as the migration rates continued to rise, as also reported by the El Paso Intelligence Center (henceforth, EPIC) (2014, pp. 3-4). Jones acknowledged, however, that his attempts to investigate temporal data were not robust enough to draw conclusions.

On the whole, most of the correlative evidence indicated a relationship between high rates of apprehensions in the United States and high homicides rates in the countries of origin. Taken together, evidence from children and other stakeholders as well as correlative evidence point to violence in the community and in the home as a driver of migration of unaccompanied children from the NTCA.

\subsection{Lack of state protection}

Children are not motivated to leave simply because of the pervasive violence, but also because of the lack of state protection against it (Rodriguez, Urrutia-Rojas, \& Gonzalez, 2017, p. 10). The police itself has in fact contributed to the general atmosphere of violence: In an attempt to crack down on gangs, it has adopted a mano dura ("iron first") approach, which

\footnotetext{
${ }^{16}$ Departments are the major territorial subdivision in the NTCA countries.
} 
licenses brutality against youth suspected of belonging to a gang (Kennedy, 2014, p. 4; Musalo \& Lee, 2017, p. 156; WRC, 2012, p. 8).

Further, several sources report that gangs have considerable power over the police (Carpenter, 2014; Schmidt, 2017a, p. 68; Stinchcomb \& Hershberg, 2014, p. 20) and that the police often acts in collusion with gangs (Casa Alianza Honduras et al., 2016, p. 41; Jaimez, 2017, p. 10, 24; WRC, 2012, p. 8). As a result, many crimes go unpunished (Torres, 2017, p. 15). The population in NTCA countries therefore has little trust in the police, as illustrated by the following vignette included in Orozco and Yansura's (2014) study:

R., a recent migrant who brought her child to the US, says she is certain that the violence in El Salvador will continue to get worse and that no one - no authority, police, or government - will do anything to change it. (p. 10)

According to KIND and HRCFMC (2017), the reigning impunity is especially pronounced in cases of sexual and gender-based violence, perhaps due to a cultural normalization of gender discrimination. A very high number of crimes of a sexual nature go unpunished, resulting in even greater vulnerability for girls (pp. 22-23). Migration therefore offers an opportunity for children to seek protection, albeit outside the borders of their country.

\section{Economic factors as drivers of migration}

This section presents evidence that children are leaving in response to economic conditions. Open coding uncovered seven subthemes related to economic factors: education, employment, poverty and income, supporting family members, food security, the quest for a "better life", and expenses related to migration. I consider education under the heading of economic factors following Lorenzen (2017). Indeed, education, employment and income are linked in several ways. First, households are often too poor to be able to afford to send children 
to school, because of the costs associated with uniforms, school supplies, and transportation (Becker Herbst, et al., 2018, p. 254; Schmidt, 2017a, p. 67). Second, adolescents as young as 12 may have to leave school in order to help support their family (Ceriani Cernadas, 2012, p. 7; Kennedy, 2014, p. 3). Indeed, many families promote the independence of children, in terms of entering the labour force, from a very young age, as a strategy to cope with poverty (Silva Hernández, 2016, p. 83). Finally, the resulting low levels of educational attainment are themselves believed to limit employment opportunities (GAO, 2015, p. 5; Schmidt, 2017a, p.67).

\subsection{Evidence from children}

Unaccompanied children in many of the reviewed studies identify economic factors as a reason for their migration. For example, Khashu's (2010) participants cited several economic motives: $26 \%$ indicated that they had migrated to work in order to send remittances to their family; $21 \%$ wanted to earn money for themselves; and $23 \%$ said they wanted to work in order to "get ahead" in life (p. 21). Likewise, the UNHCR (2014a) study in the United States found that $51 \%$ of the 404 participants had an economic motive (such as poverty or a lack of "meaningful opportunities"; $25 \%$ stated they were "seeking a better future"), and 19\% cited education (p. 24); the UNHCR (2014b) study in Mexico reported that $29.2 \%$ of the 272 children interviewed named economic factors (p. 43). Of the 241 participants in Lorenzen's (2017) survey, 57.7\% invoked economic motives and $27.8 \%$ named education (p. 754). ${ }^{17}$ CONAPO (2016) reports that $59.2 \%$ of unaccompanied children admitted to migrant shelters in Mexico in 2015 cited economic factors in their intake interview (p. 166).

Many children expressed that they had migrated to find work to support their family (e.g.

\footnotetext{
${ }^{17}$ Respondents to Lorenzen's (2017) survey were allowed to check off as many causes for migration as relevant; these categories are therefore not mutually exclusive.
} 
Jaimez, 2017, p. 25). Some of them explained that they had a sick parent or were being raised by their grandparents who were too old to work (Becker Herbst et al., 2018, p. 255; Khashu, 2010, pp. 24-25), or that the main breadwinner in the household had passed away (Tello et al., 2017, p. 364). Others articulated a desire to provide for their siblings and to finance their education, as illustrated in this quote from a participant in Becker Herbst et al.'s (2018) study, which expresses a combination of motives related to supporting the family:

The reason that I immigrated is because my father is very sick in his stomach, and my siblings want to keep studying and we don't have a good income in order to send them to school; they cry because sometimes we do not have food to eat, in a few words I immigrated because of the necessity of helping my family. (p. 255)

Some children indicated they had migrated to secure "stable housing" (Becker Herbst et al., 2018, p. 253). Many pointed specifically to food insecurity as the cause of their migration:

Lack of food, money, and work; for a better future for my family, because we didn't have enough food (Casa Alianza Honduras et al., 2016, p. 18; my translation)

Above all, children saw migration as a path to a "better" future or life (Becker Herbst et al., 2018, p. 256; Jaimez, 2017, p. 25), or in fact to any future at all (Casa Alianza Honduras et al., 2016, p. 42).

\subsection{Evidence from other stakeholders}

The views expressed by child migrants about their lack of educational and employment opportunities were shared by other stakeholders. In Orozco and Yansura's (2014) survey of adult Central American immigrants in the United States, $29 \%$ of respondents named "a lack of economic opportunity" in their country of origin as a cause for the migration of unaccompanied children (p. 15). Moreover, recognizing their own poverty, parents understood migration to be 
the best solution to improve their children's lot in life (Jaimez, 2017, pp. 32-33). In addition, the World Food Programme detected "an increased reliance on migration as a coping strategy" for food insecurity in the NTCA in 2014 (WFP \& IOM, 2016, p. 7). Five percent of households in El Salvador, ten percent in Honduras, and twelve percent in Guatemala had at least one member who had recently migrated due to drought (although this migrant may not necessarily have been a child) (WFP \& IOM, 2016, p. 24).

The Guatemalan NGO staff members interviewed by Nichols et al. (2017) emphasized the role of education as a driver of the migration of unaccompanied children. Although some of them acknowledged that the employment situation in the country is so dire that even higher education would likely not result in improved job prospects, others pointed to education as a “deterrent to migration" (p. 1974). Similarly, in an opinion piece published in 2014, Mexican columnist Andrés Oppenheimer cited studies suggesting that educational attainment led to a decreased likelihood of migration. Similar evidence was also quoted by a U.S. official stationed in Honduras (GAO, 2015, p. 5). Oppenheimer further argued that dropping out of school paved the way for young Central Americans to join gangs.

In addition, some U.S. government officials indicated that economic factors may also operate in a different direction. The vast majority of unaccompanied children-75\% to $80 \%$, as reported by Kandel, Bruno, Meyer, Seelke, Taft-Morales, \& Wasem (2015, p. 464) and Stinchcomb and Hershberg (2014, p. 12) — travel overland with a smuggler acting as a guide and facilitating border crossings. The ability to hire a smuggler, however, is contingent on financial resources - the going rates range between US\$ 2,000 and US\$ 10,000 (CONAPO, 2016, p. 54; Stinchcomb \& Hershberg, 2014, p. 12), and there are reports of families taking out loans (Stinchcomb \& Hershberg, 2014, p. 13), handing over the title of their property to lenders (Cao, 
2017, p. 16), or mortgaging their house (KIND \& HRCFMC, 2017, p. 16) in order to afford these services. Children from families who are too poor to afford smuggler's fees may be denied the opportunity to migrate to improve their living conditions (GAO, 2015, p. 7). Migration may therefore require a certain minimum threshold of economic resources. ${ }^{18}$ As we will see in the next subsection, this hypothesis appears to be borne out by some correlative evidence.

\subsection{Correlative evidence}

The assumption underlying hypotheses about the relationship between economic factors and migration is that both poor economic conditions in the country of origin (acting as a "push" factor) and favourable economic conditions in the destination country (exerting a "pull" on prospective migrants) may have a positive correlation with the migration rates of unaccompanied children. Economic factors have been quantified in different ways by different researchers. For ease of exposition, Table 7 summarizes the indicators used to test the relationship between the migration of unaccompanied children from the NTCA and economic factors in their countries of origin and in the United States.

\footnotetext{
${ }^{18}$ In spite of the obstacle represented by financial resources, $20 \%$ to $25 \%$ of unaccompanied children do travel without a smuggler, per the figures disclosed by Kandel et al. (2015) and Stinchcomb and Hershberg (2014) cited in the body of the text. One alternative option available to children who have fewer economic means is to cross Mexico atop cargo trains (Amuedo-Dorantes \& Puttitanun, 2016, p. 106). Torres (2017, pp. 56-57) argued that the reopening of a cargo train line starting right at the Mexico-Guatemala border in 2014, coinciding with the "surge" of the flow of unaccompanied children through the region, represented a crucial enabling factor for the children who chose this route.
} 
Table 7. Summary of economic indicators examined in sample

\begin{tabular}{|l|l|}
\hline Economic indicator & $\begin{array}{l}\text { Statistically significant relationship } \\
\text { with the number of apprehensions } \\
\text { of unaccompanied children? }\end{array}$ \\
\hline \multicolumn{2}{|l|}{ In NTCA (push factors) } \\
\hline Human Development Index (Orozco \& Yansura, 2014) & No \\
\hline GDP per capita (Amuedo-Dorantes \& Puttitanun, 2016) & Yes \\
\hline Unemployment rate (Jones, 2017) & No \\
\hline Poverty rate (Clemens, 2017; Jones, 2017) & Mixed \\
\hline Income (Clemens, 2017) & Mixed \\
\hline Food availability (WFP \& IOM, 2016) & Yes \\
\hline In United States (pull factors) & \multicolumn{2}{|l|}{} \\
\hline $\begin{array}{l}\text { Median weekly earnings (Amuedo-Dorantes \& \& } \\
\text { Puttitanun, 2016) }\end{array}$ & Yes \\
\hline $\begin{array}{l}\text { Unemployment rate (Amuedo-Dorantes \& Puttitanun, } \\
\text { 2016; Jones, 2017) }\end{array}$ & Yes \\
\hline
\end{tabular}

In terms of the conditions in the country of origin, the studies do not provide consistent evidence of a positive correlation between economic factors and the migration of unaccompanied children. On the one hand, WFP and IOM (2016) uncovered a statistically significant positive correlation between food insecurity and migration from the NTCA (although the study considered overall migration, not just that of unaccompanied children) (p. 24). Likewise, Amuedo-Dorantes and Puttitanun (2016) found that growth of the GDP per capita in the NTCA countries was negatively related to the migration rate of unaccompanied children (suggesting that an improvement of economic conditions in the country of origin lead to a decrease in migration) (pp. 112-113). One the other hand, Jones (2017) found no correlation between the open unemployment rate in the NTCA and the migration rate of unaccompanied children, ${ }^{19}$ or between the proportion of the population living in poverty and the migration rate of children (pp. 348349). Similarly, Orozco and Yansura (2004) detected only a weak and inconsistent correlation

\footnotetext{
${ }^{19}$ Jones (2017) recognizes, however, that the official unemployment rates in the NTCA mask a high rate of participation in the informal labour market composed of "part time, temporary, casual jobs" (p. 344).
} 
between the Human Development Index (a measure combining life expectancy, education, and income indices) and the migration of unaccompanied children (pp. 7-8). In addition, Clemens (2017) discovered a curvilinear relationship between migration, income, and the poverty rate in the municipalities of origin. Contrary to expectations based on the data collected directly from migrant children, migration does not always correlate with poverty and low income. Migration rates are low not only in municipalities where the average income is high, but also in municipalities where the average income is extremely low or where the poverty rate is extremely high (p. 22). These findings are therefore consistent with the hypothesis that migration requires a certain threshold of financial resources. In sum, based on the data cited in the sources sampled, the relationship between migration and economic factors in the country of origin is not clear-cut.

As for the relationship between economic conditions in the United States and the migration of unaccompanied children, Amuedo-Dorantes and Puttitanun (2016) found that increases in the weekly median income significantly corresponded with increased migration rates, and that a rise in the unemployment rate was negatively related to the migration rate (p. 112), a result confirmed by Jones (2017, pp. 348-349). Thus, these results imply that children from the NTCA may be attracted by favourable conditions in the United States.

Triangulating the data from child migrants, other stakeholders, and correlative evidence, I conclude that economic factors are a major driver of this migration. I will revisit the relative contributions of push and pull factors in the discussion in Chapter 4.

\section{Parental absence as a driver of migration}

I identified three subthemes related to family during open coding: family reunification, the parents' history of migration, and domestic neglect. Chavez and Menjívar (2010) had already identified family reunification as one of the main drivers of the migration of unaccompanied 
children from the NTCA almost a decade ago. Indeed, 58\% of the Honduran deportees interviewed by Casa Alianza Honduras et al. (2016) had at least one parent living outside the country (in the United States in $98 \%$ of cases) (p. 15). Similarly, over $50 \%$ of the Salvadoran deportees interviewed by Kennedy (2014) had one or both parents in the United States (p. 1). In recent years, the tightening of U.S. immigration policy and the concomitant securitization of the U.S.-Mexico border has made family reunification more difficult, especially for undocumented migrants, and has resulted in protracted family separation (Chishti \& Hipsman, 2015, pp. 97-98; Donato \& Sisk, 2015, p. 62).

In addition, many migrant children are orphans (Khashu, 2010, p. 25). Four of every ten unaccompanied children interviewed by the UNHCR (2014b) in Mexico had at least one deceased parent, and $2 \%$ of the respondents lived by themselves at the time of their migration (p. 39). The next sections examine how migration can be a response either to a desire to be reunited with one's parents, or to an absence of familial support.

\subsection{Family reunification as a driver of migration}

\subsubsection{Evidence from children}

In the UNHCR (2014b) study in Mexico, 22.2\% of participants had left their country of origin in order to be reunited with their migrant parents (p. 42). Lorenzen (2017) found that $37.8 \%$ of the children he surveyed cited family reunification as a cause of their migration (p. 758). In a review of intake data collected in shelters for migrant youth in Mexico, CONAPO (2016) reported that family reunification had in fact grown in strength as a major cause of migration between 2013 and 2015, from $16.7 \%$ to $31.4 \%$ (p. 166).

Data for individual countries of origin reaffirm the importance of family reunification. A 
survey of migrant children conducted by the Guatemalan government in 2010 indicated that $11.7 \%$ of respondents answered that they had migrated to be reunited with family (cited in Hurtado Paz y Paz, Girón Solorzano, \& Ibarra González, 2015, p. 158). Approximately one third of Kennedy's (2014) Salvadoran participants named family reunification as a one of their main reasons for migrating (p. 1).

The desire for family reunification is explicitly identified as a motive for migration in the following quotations drawn from Becker Herbst et al.’s (2018) study:

(1) [B]ecause I did not know my mother and because I only lived with my grandmother. (p. 254)

(2) The reason that I came was because [of] my mother, because I miss her a lot. (p. 255)

\subsubsection{Evidence from other stakeholders}

Orozco and Yansura (2014) reported that, in their survey of adult immigrants from the NTCA, between $12 \%$ and $16 \%$ of respondents named family reunification as the main cause for the migration of unaccompanied children (p. 15). The Guatemalan NGO staff members interviewed by Nichols et al. (2017) affirm that it is not only children who wish to be reunited with parents, but also migrant parents who plan to send for their children once they are economically stable and the children are old enough to make the journey on their own (p. 1979). The editor of a Guatemalan digital news outlet interviewed by Planas (2014) stated that family reunification was the main factor motivating Guatemalan children to leave their homes.

\subsubsection{Correlative evidence}

It is difficult to quantify the desire for family reunification in such a way as to test its 
correlation with migration patterns. Donato and Sisk (2015), however, tested a related hypothesis - that a parent's history of migration predicts the likelihood that their offspring will migrate as children. They found that migrants from El Salvador (who were adults at the time of the survey), were likelier to have migrated for the first time as children if their parents had already migrated: Close to $11 \%$ of the respondents with migrant parents migrated for the first time as children, contra $4 \%$ of those without migrant parents (Figure 1, p. 68). This is consistent, though not synonymous, with the claim that the migration of unaccompanied children is motivated by family reunification. However, Donato and Sisk's results must be interpreted with a grain of salt for several reasons. They had no data for Honduras, the data from El Salvador were not robust enough to establish a statistically significant correlation, and they were contradicted by the data from Guatemala, where the proportion of respondents without migrant parents who had first migrated as minors was slightly higher than that of respondents with migrant parents. Further, the data were collected from individuals who migrated long before the current wave of unaccompanied child migration, which potentially limits the generalizability of the results. The findings from Salvadoran migrants are nevertheless coherent with the data collected from unaccompanied children from across the NTCA and from other stakeholders.

\subsection{Family breakdown as a driver of migration}

\subsubsection{Evidence from children}

For some children, it is family breakdown, that is, a lack of attachment to family members, or a desire to escape them, that triggers migration. Familial breakdown is caused either by the literal absence of the parents (due to migration, death, or abandonment) or by a more figurative absence, that is, neglect (Schmidt, 2017b). 
Children in multiple studies described indifference from the relatives with whom they lived after the passing of their parents:

(1) Nobody took care of me in my country because I don't have people to take care of me, because they died. (quoted in Becker Herbst, 2018, p. 254)

(2) Me, my family doesn't treat me well. There's a lot of aggression, and since my parents aren't around anymore, I preferred being in the street than at home. I was better off going to Mexico with a friend, where I was told I could find work... (quoted in UNHCR, 2014b, p. 20; my translation)

(3) I was better off leaving. My family stopped protecting me a long time ago ... (quoted in UNHCR, 2014b, p. 20; my translation)

One of the most critical manifestations of familial neglect was a lack of protection against physical harm, which increased the vulnerability of children and incited them to migrate (UNHCR, 2014b, p. 20), as illustrated by the life story of a participant in the KIND and HRCFMC (2017) study:

Karla is a 16-year-old study participant from El Salvador. Her father migrated to the United States when she was a baby. Shortly after, her mother moved to a town several hours away to work and left Karla under her grandparents' care. When Karla was 11 years old her grandmother migrated to the United States and sent Karla to live with her uncle in the capital city. One year later her uncle decided that he could not care for Karla and sent her back to her hometown to live with another uncle. This uncle raped and sexually abused Karla on multiple occasions. Karla told family members living in the area but they did not report the crime to the authorities, and the abuse continued. Convinced that there was no one in El Salvador who would protect her, Karla traveled alone to the United States. (p. 13)

\subsubsection{Evidence from other stakeholders}

NGO staff in Guatemala and U.S. government officials stationed in the three NTCA countries concur that "dysfunctional" parenting (GAO, 2015, p. 6) and "disintegration" of the 
family (Nichols et al., 2017, p. 1977) are partially responsible for the migration of unaccompanied children. Further, family breakdown also represents a risk factor for joining a gang. Indeed, several studies highlight that children of absent or deceased parents are vulnerable to recruitment (e.g., Lorenzen, 2017, p. 758; Stinchcomb \& Hershberg, 2014, p. 22).

In sum, data from unaccompanied children and from other stakeholders indicate that parental absence plays a polyvalent role in the migration of unaccompanied children. Aside from the oft-cited quest for family reunification, the absence of supportive familial relationships may also incite children to embark on a migration journey.

\section{Perceived ease of entry into the destination country as a driver of migration}

A fourth factor that has been proposed to explain the increase in unaccompanied child migrants from the NTCA is the perceived ease of entry into the destination country based on its immigration policy. For example, Mexico passed a law in 2011 requiring Central American migrants to possess a visa when entering the country, ostensibly to protect the rights of migrants and to better monitor entries into the country (Kandel et al., 2015, p. 454). This legislation has been misinterpreted by some as a transit visa facilitating the passage of migrants through Mexico toward the United States (Kandel et al., 2015, p. 465). Consequently, some observers have suggested that the increased flows of migrant youth may have been influenced by these legislative reforms (p. 454).

More attention has been devoted to the influence of U.S. immigration policy. Several politicians blamed the 2014 "surge" of unaccompanied child migrants on the belief —allegedly promoted by Central American media outlets (EPIC, 2014, p. 2; Planas, 2014) or by smugglers trying to expand their business (Chishti \& Hipsman, 2015, p. 100; Stinchcomb \& Hershberg, 
2014, pp. 12-13) - that policies introduced during the Obama and Bush administrations were favourable to unaccompanied children (Cajina \& Orozco, 2016, p. 4). Indeed, it has been noted that the increase in the apprehensions of unaccompanied child migrants from the NTCA followed the passing of two pieces of legislation affecting undocumented child migrants' ability to stay in the U.S.: the Trafficking Victims Protection Reauthorization Act (TVPRA), passed in 2008, and the Deferred Action for Childhood Arrivals (DACA) policy, passed in 2012 (AmuedoDorantes \& Puttitanun, 2016). According to the TVPRA, unaccompanied children apprehended by USCBP who are from countries that are not "contiguous" to the United States are granted the possibility of submitting an asylum claim and must be released into the care of a relative or other suitable guardian until their hearing (Amuedo-Dorantes \& Puttitanum, 2016, p. 104; Chishti \& Hipsman, 2015, p. 98). However, the "under-resourced and overburdened" (Chishti \& Hipsman, 2015, p. 99) immigration system is characterized by heavy backlogs of hearings and deportations (Chishti \& Hipsman, 2016, "Beyond the Push Factors" section; Robles, 2014). As a result, unaccompanied children often end up staying in the United States for several months, if not years, while they wait for their cases to come before a judge (Amuedo-Dorantes \& Puttitanun, 2016, p. 104; Chishti \& Hipsman, 2015, p. 99; Clemens, 2017, p. 5; Rosenblum, 2015, p. 14). These long stays may have fostered the perception in the countries of origin that children would easily receive an authorization, or permiso ("permit"), to lawfully remain in the United States (CONAPO, 2016, p. 63; Preston, 2014; Rosenblum \& Ball, 2016, p. 5).

DACA is also thought to have contributed to the impression that children would be granted permission to stay in the United States. This policy provides a two-year renewable deferral from deportation, and a work authorization (Amuedo-Dorantes \& Puttitanun, 2016, p. 103), to undocumented immigrants who arrived in the country as children (under the age of 
16) prior to 2007 and were enrolled in, or had graduated from, high school (Chishti \& Hipsman, 2015, p. 100). ${ }^{20}$

The four subthemes related to this driver that were revealed by open coding are the effects of TVPRA, the impact of DACA, rumours about a permit that would allow unaccompanied minors to lawfully remain in the United States, and the role of smugglers and the media in disseminating misinformation about U.S. immigration policy. I now examine the evidence in support of the claims that the understanding of U.S. immigration policy as welcoming to children was widespread and contributed to the increase in the numbers of unaccompanied child migrants.

\subsection{Direct evidence from children}

There is anecdotal evidence that some unaccompanied children from the NTCA believed that they would easily be granted a permiso to stay in the United States, as attested by this quote from a Honduran teenager who was apprehended in Mexico on his way to the United States:

If you make it, they take you to a shelter and take care of you and let you have permission to stay.... When you appeal your case, if you say you want to study, they support you. (quoted in Robles, 2014)

The main source of quantitative evidence of the role of perceptions that U.S. immigration policy was favourable to unaccompanied children is a report by EPIC (2014) that cited interviews conducted by USCBP with 230 families and unaccompanied children, in which 219 respondents named this factor as their "primary reason for migration" (p. 2). Despite this

\footnotetext{
${ }^{20}$ It has also been hypothesized that debates about comprehensive immigration reform in the U.S. Congress in 2013 and 2014 had given members of separated families hope that they would be able to reunite imminently (Kandel et al., 2015, pp. 470-471). Parents may have sent for their children in the hopes that they would be able to benefit from an eventual amnesty program (Chishti \& Hipsman, 2015, p. 98; Torres, 2017, pp. 58-59), or out of impatience once it became clear that no new legislation would be passed (Chishti \& Hipsman, 2015, p. 98).
} 
impressive proportion, the credibility of the study is undermined by the fact that it provides no information on any other responses given or on the interview instrument and procedures (U.S. Senate, 2015, p. 19). In addition, it is unclear how many of the 230 participants were unaccompanied children. Moreover, only one other study that collected data from children mentions this factor: In the UNHCR (2014a) study in the United States, a single respondent invoked it as a cause of their migration (p. 31).

\subsection{Evidence from other stakeholders}

The WFP and IOM (2016) study cited sources from the Guatemalan Ministry of Social Development who link the increase in migration of unaccompanied youth from that country to efforts by smugglers to disseminate misinformation about the relative ease with which children are admitted to the United States (p. 26). This finding is echoed by the Guatemalan NGO staff members interviewed by Nichols et al. (2017) (who, for their part, assign responsibility to the media [p. 1983] $]^{21}$ ). Robles (2014) quoted a Salvadoran immigration official who believed that Central Americans "were left with the sense that the United States had 'opened its doors' to women and children."

Torres (2017) supplied quantitative evidence that was indicative of the widespread nature of the rumours. He polled residents of NTCA countries who knew an unaccompanied child who had migrated recently. When asked about their opinions about how those children would be treated in the United States, $76 \%$ of respondents stated that they believed that the children would be allowed to stay in the United States; only $23 \%$ believed that the children would be deported; and $68 \%$ believed the U.S. government would help locate the relatives of the children (p. 48).

\footnotetext{
${ }^{21}$ Planas (2014) examined the coverage of DACA in several Central American newspapers and concluded that the reports generally presented an accurate description of the policy and of its consequences and often highlighted the high number of deportations carried out during Obama's term.
} 


\subsection{Correlative evidence}

Researchers have tested the relationship between migration rates and the introduction of laws and policies appearing to be favourable to child migrants, such as the TVPRA and DACA. Jones (2017) found that the period in which the flow of unaccompanied child migrants increased corresponded with a stretch in which seemingly lenient policies were introduced (pp. 348-349). Clemens (2017), however, used more stringent measures of statistical significance and discovered no such relationship (p. 24). Finally, Amuedo-Dorantes and Puttitanun (2016) performed a regression analysis that showed a relationship between the passing of TVPRA and the apprehensions of child migrants, but found none with DACA (p. 112). The correlative evidence about the relationship between perceptions of laxness of U.S. immigration policy and the migration of unaccompanied children is therefore inconsistent.

On the balance, there is credible evidence that rumours about a permiso did exist and that they played a role in the decision calculus of unaccompanied children and their parents. There is, however, less evidence supporting the assertions of several politicians who cited it as the primary driver of the surge of 2014 (as reported in Chishti \& Hipsman, 2014, "Why Is This Happening?" section; Preston, 2014).

Finally, it is worth noting that of the 25 sources in my sample that engaged with the claims about U.S. immigration policy, only 3 are in Spanish (and one of these is written by an American), which suggests that this factor is not of great concern outside of the United States. Since unaccompanied children from the NTCA are also migrating to other countries, pull factors in one destination country cannot tell the whole story. 


\section{Intersections between demographic characteristics and drivers of migration}

Acuña González (2016) warns against homogenizing the population of unaccompanied child migrants, because the drivers of migration vary by demographic characteristic such as age group and nationality (p. 51). Indeed, open coding established five demographic factors that may influence a child's motives for migration: age, gender, nationality, ethnicity, and sexual orientation and identity.

\subsection{Drivers by age and gender}

Lorenzen (2017) observed a difference in the drivers of migration selected by his participants based not only on their age (whether they were 14 years old or younger, or whether they were 15 or older), but also on their gender (boys vs. girls). He found that nearly half of the boys and children over 15 were migrating for purely economic reasons. In contrast, more than $40 \%$ of girls and of children 14 or younger stated that they were migrating exclusively to reunite with family members (p. 762). Kennedy (2014) also found that, among Salvadorans, girls and younger children were likelier to migrate for family reunification (p. 3).

Moreover, Lorenzen (2017) noted that boys and older adolescents were more vulnerable to violence in the community (and specifically to recruitment by gangs) (p. 762) - a result also reported by the UNHCR in Mexico (2014b, p. 43) and the United States (2014a, p. 27, 28, 29)but that girls were exposed to a greater range of types of violence, including, as noted by KIND and HRCFMC (2017, p. 12) and WRC (2012, p. 8), rape and other types of gender-based violence. The quote below, from a 16-year-old Salvadoran migrant, expresses the plight of girls in the NTCA: 
In El Salvador they take young girls, rape them and throw them in plastic bags. (quoted in UNHCR, 2014a, p. 34)

In addition, Schmidt (2017b) reported that girls were likelier to invoke domestic abuse and violence as a cause for their migration. Boys also reported maltreatment in the home, but they were less likely to identify it as a cause for migration (p. 59).

\subsection{Drivers by nationality}

The NTCA is generally treated as a single bloc, with sources emphasizing the similarities in the conditions in the three countries (as I have done in Chapter 1). Some studies do, nevertheless, reveal differences across countries. For example, several studies reported that Guatemalan children more frequently named economic factors as the main cause of their migration, while violence in society played a bigger role in the decision calculus of children from Honduras and El Salvador. In Lorenzen's (2017) sample, 56\% of Guatemalan children cited only economic factors as the cause of their migration; in contrast, only $37.5 \%$ of Hondurans and

$28.2 \%$ of Salvadorans named these as the sole driver (p. 760). As for violence, $4 \%$ of Guatemalans named it as the only motivation for migration, compared to $12.5 \%$ of Hondurans and $10.3 \%$ of Salvadorans (p. 756).

In addition, some studies report that Salvadorans are likelier to name family reunification as a cause for their migration (e.g., Lorenzen, 2017, p. 759). Indeed, the UNHCR (2014b) study in Mexico notes that more Salvadoran than Honduran or Guatemalan children had parents who lived in the United States (p. 39). 


\subsection{The migration of specific groups}

\subsubsection{Ethnic minorities}

Indigenous children in Guatemala are the only ethnic minority that receives even modest coverage in the sources reviewed. Forty-eight percent of the children in the Guatemalan subsample of the UNHCR (2014a) study in the United States were Indigenous (p. 34). A disproportionate number of them cited economic deprivation as the cause of their migration, a result confirmed by WFP and IOM (2016, p. 27). Although discussing the conditions of their migration journey is beyond the scope of this paper, it should be mentioned that Indigenous child migrants are particularly vulnerable because they do not always speak Spanish, which impedes communication. Even those who do speak Spanish are the target of discrimination and abuse by Spanish-speaking migrants due to deep-seated racism (Hurtado Paz y Paz et al. 2015, p. 169, 171).

\subsubsection{Sexual minorities}

The KIND and HRCFMC (2017) study on the connection between migration and sexual and gender-based violence against youth describes "widespread homophobia and discrimination against LGBTI communities" (p. 12) in the NTCA. Children who identify as LGBTI ${ }^{22}$ are vulnerable to abuse within their own home (p. 18) and to persecution outside of it (p. 19). They are targets for extortion and violence from gangs on the basis of their sexual orientation, but crimes against them tend to go unpunished (p. 19). Further, none of the NTCA countries have organizations that support LGBTI children who are survivors of violence (p. 24). These conditions suggest that LGBTI children may be particularly motivated to migrate, but none of the studies reviewed could provide concrete data addressing this question. The UNHCR (2014b)

\footnotetext{
${ }^{22}$ Although nomenclature varies, I am using the initialism "LGBTI" following both KIND and HRCFMC (2017) and UNHCR (2014b), the two sources in my sample that discuss this population in most detail.
} 
study in Mexico tried to include LGBTI youth, but was not able to sample any children who openly identified as such (p. 36). This finding underscores the challenges of studying the migratory behaviour of marginalized social groups.

\section{Summary of findings}

This chapter has presented direct evidence from migrant children, opinions of state officials and other stakeholders who work closely with youth or their parents, and correlative evidence of links between migration trends and various conditions in the countries of origin or of destination. This array of evidence answers the main research question of this MRP, which is "What are the factors driving the migration of unaccompanied children from the NTCA?" Three main sets of drivers underlie the migration of unaccompanied children: violence in the home and in society, economic conditions in the countries of origin and destination, and parental absence. In addition, there is evidence that an interpretation of U.S. immigration policy as being favourable to children has also factored into the migration decision calculus.

The findings presented in this chapter demonstrate that multiple factors are driving the current flow of unaccompanied children out of the NTCA. Different children have different reasons for migrating, as suggested by the findings by age and gender. Further, children from the different countries also have slightly different motives. Moreover, a single child may have multiple reasons for migrating. Indeed, 31.1\% of Lorenzen's (2017) participants named two or more motives (p. 755). Chapter 4 will explore the connections between the identified drivers. 


\section{CHAPTER 4. DISCUSSION.}

As announced in Chapter 2, this chapter presents the results of selective coding. This third and final stage of coding identified connections between the drivers described in Chapter 3 . These links provide answers to the two subsidiary research questions posed in Chapter 1: "Are unaccompanied children from the NTCA motivated chiefly by push or pull factors?" and "Are unaccompanied children from the NTCA primarily migrating for economic reasons, to flee from violence, or because of a combination of the two factors?" I will also confront traditional models of migration with the case of unaccompanied children from the NTCA, based on the answer to the second question. I will conclude with a brief discussion of migrant agency.

\section{Push and pull factors in the migration of unaccompanied children from the NTCA}

Of the four sets of factors discussed in Chapter 3, violence clearly falls on the push end of the spectrum of the drivers of migration, while the perception of ease of entry into the destination country unequivocally belongs at the pull end. Parental absence and economic factors can, for their part, function as either push or pull factors. In Chapter 3, I made a distinction in the parental absence category between family reunification and family breakdown. The desire to be reunited with family living abroad acts as a pull factor; however, disintegration of familial ties and a resulting lack of protection from violence inside and outside the home may represent a push factor. In the remainder of this chapter, I will focus solely on family reunification (because it is more frequently discussed in the sources reviewed), and will therefore consider only the pull aspects of parental absence. As for economic factors, as demonstrated by the correlative evidence, they combine push (poor conditions in the country of origin) and pull (relatively more prosperous circumstances in the destination country) factors. However, the fact that several child participants stated that they would not have left their country had it not been for their intolerable 
economic situation (e.g. Schmidt, 2017a, p.72) suggests that economic conditions are experienced as a push, rather than a pull, factor. I will therefore treat economic circumstances exclusively as a push factor in the remainder of this chapter.

To answer the question of whether unaccompanied children are motivated more by push (i.e., violence and economic factors) or pull (i.e., ease of entry to destination country and family reunification) factors, I will introduce a distinction between causes and enabling factors (loosely based on Van Hear's typology of the factors involved in a migratory calculus, as expounded in Lorenzen, 2017, footnote 15 , p. 758). ${ }^{23}$ By causes, I mean both underlying structural conditions in the country of origin (such as a lack of opportunity and widespread violence) and immediate triggers of migration (such as a specific threat from a gang member). By enabling factors, I am referring to circumstances that make migration a viable option, by, for example, suggesting a destination country. I contend that causes, rather than enabling factors, should be understood as the fundamental motivation for migration. The next two subsections will present evidence that demonstrates that the pull factors invoked here are enabling factors rather than causes of the migration of unaccompanied children from the NTCA.

\subsection{Perceptions of ease of entry to the United States as an enabling factor}

As I concluded in Chapter 3, there is convincing evidence that in 2014 many Central American parents and children believed that U.S. immigration policy was favourable to unaccompanied children (and mothers with young children). However, child migrants first move within their own country to seek better and safer conditions (Stinchcomb \& Hershberg, 2014, p. 13), and they are also migrating to countries other than the United States in growing numbers

\footnotetext{
${ }^{23}$ Van Hear (1998) distinguishes between underlying structural factors, proximate causes (i.e., specific instantiations of the underlying causes), precipitating causes (i.e., immediate triggers), and enabling factors of migration.
} 
(U.S. Senate, 2015, p. 13; Musalo \& Lee, 2015, p. 152; Rosenblum \& Ball, 2016, p. 4). These two observations suggest that the flow is determined not by the destination country, but by conditions in the countries of origin. The case of a Honduran woman interviewed by Preston (2014) signals the true role of perceived ease of entry into the United States in a migrant's decision calculus: "Leiby Mejía ... came from Honduras with two sons, 5 and 7, said she heard the permit rumor, then fled after a narcotics gang killed a cousin living nearby." Thus, a specific instantiation of violence was the immediate trigger for her migration, and the rumours about lenient U.S. immigration policy offered a possible solution and a destination.

\subsection{Family reunification as an enabling factor}

As mentioned in Chapters 1 and 3, family reunification has long been presented as a major cause for the migration of unaccompanied children. However, several studies note that the children who name family reunification as a cause for migration represent only a modest proportion of the total number of migrant children who had relatives in the destination country. For example, in Khashu's (2010) study, $83 \%$ of respondents had family in the United States (including $17 \%$ who had a parent, and $28 \%$ who had a sibling), but only $12 \%$ of all participants named family reunification as the cause of their migration (p. 22, 26). The UNHCR (2014a) study conducted in the United States reports a similar result: Of the $36 \%$ of children interviewed who had a parent in the United States, only 59\% identified family reunification as their reason for leaving their country (p. 24). Likewise, only $35 \%$ of the Salvadorans interviewed by Kennedy (2014) cited family reunification as the cause of their migration, even though more than $50 \%$ of her sample had a parent in the United States (p. 3). Findings like these lead Lorenzen (2017) to conclude that family reunification functions as a "compass" for, rather than as a cause of, 
migration (p. 758). The presence of relatives abroad plays an important role in determining the choice of destination country, and may help ensure the financing of the trip, but it does not necessarily trigger it.

This is consistent with the responses of unaccompanied children to the question of why they or their parents had suddenly decided to reunite after years of separation. Several participants in Kennedy's (2014) study indicated that they wanted to be with their parents because it gave them the possibility to flee violence in their country of origin. The author concluded that children first decided to leave (or their families decided they should escape), and then chose their destination based on where they had relatives (p. 3). Jaimez (2017) likewise asserted that her participants only began to consider reunification with a parent in the United States after receiving threats from gang members (e.g., p. 35. 37). Finally, commenting on similar data, the UNHCR (2014b) study in Mexico proposed that family reunification was best understood as a coping strategy against violence, and therefore as a consequence of migration, rather than as its cause (p. 64).

A Casa Alianza Honduras et al. (2016) study presented the situation from the perspective of Honduran parents who live abroad. When they discovered the dangerous conditions faced by their children in the country of origin, they sent for them, paying extravagant sums to smugglers (p. 29). Thus, as with the perceived ease of entry to the United States, violence was the trigger for migration, and family reunification provided a solution.

The relationship between immediate threats of violence and the possibility of family reunification is strikingly illustrated through the words of a 15-year old Salvadoran girl interviewed by the UNHCR (2014a) after she arrived in the United States. Although she had long been separated from her mother, she decided to leave her country only after attracting the 
attention of gang members:

I am here because the gang threatened me. One of them "liked" me.... [Gang members] said if I was still there on April 8, they would grab me, and I didn't know what would happen. I also wanted to come because I was excited about seeing my mother. ... . My mother's plan was always for the four of us - her, my two sisters and me - to be together. But I wasn't sure I wanted to come. I decided for sure only when the gang threatened me. (p. 34)

This is not to say that family reunification is never the principal cause for the migration of unaccompanied children. Nevertheless, various types of evidence indicate that, for many children, it is an enabling factor rather than an underlying or immediate cause.

To summarize, among the drivers of the migration of unaccompanied children from the NTCA, the two pull factors largely act as enabling factors rather than as causes. I therefore conclude that the two push factors of violence and poor economic conditions in the countries of origin are the primary motivations for the migration of unaccompanied children from the NTCA.

\section{Are unaccompanied children seeking better economic conditions or fleeing violence?}

Several sources acknowledge that many children have multiple reasons for migrating (e.g., Cajina \& Orozco, 2016, p. 4; Casa Alianza Honduras et al., 2016, p. 31; Chishti \& Hipsman, 2014, "Why Is This Happening?” section; Chishti \& Hipsman, 2015, p. 100; Hurtado Paz y Paz et al., 2015, p. 156; Kandel et al., 2015, p. 455; Khashu, 2010, p. 22; Lorenzen, 2017; UNHCR, 2014a, pp. 17, 23; UNHCR, 2014b, p. 38). Still, a number of the empirical studies I reviewed attempted to establish whether unaccompanied children were primarily motivated by a desire to seek out better economic opportunities, or by a need to seek protection from violence. I will start by discussing the studies that collected data from children and reported their findings in such a way as to enable a comparison of the proportions of responses for both causes. I will assume that the higher the proportion of children who cited a particular cause, the greater the 
importance of that factor. Then, I will present correlative evidence that simultaneously tested the relative importance of violence and of economic factors.

\subsection{Evidence from children}

Two studies reported that violence was the most frequently identified cause for migration. In the UNHCR (2014b) study in Mexico, $48.6 \%$ of the participants cited violence as a cause for their migration, and 29.2\% named economic factors (p. 41). Likewise, Casa Alianza Honduras et al. (2016) revealed that a combined $66 \%$ of deported Honduran children named violence in society $(58 \%)$ or at home $(8 \%)$, while only $22 \%$ named poverty and a lack of opportunities (p. 32).

Conversely, three studies place economic factors on top. In Lorenzen's (2017) study, $57.7 \%$ of unaccompanied children surveyed stated that they had migrated for economic reasons, $27.8 \%$ invoked educational reasons, ${ }^{24}$ and only $24.9 \%$ named violence in society (p. 75$){ }^{25}$ Likewise, CONAPO (2016) reports that economic factors were the reason named most often by participants surveyed in Mexican shelters in both 2013 and 2015, although the relative importance of this category had diminished over time, from $66.1 \%$ to $59.2 \%$. Trailing far behind, violence in society was mentioned by $3.8 \%$ of children in 2015, down from $6.3 \%$ in 2013 (p. 166). These findings mirror the results reported a few years earlier by Khashu (2010), even though she had collected her data as early as 2008 . The vast majority, or $70 \%$, of her participants cited factors related to economic considerations, while only $6.5 \%$ named violence at home or in society (p. 22).

\footnotetext{
${ }^{24}$ Since Lorenzen's survey encouraged respondents to select all relevant causes, there may be overlap between participants who selected economic and educational reasons.

${ }^{25}$ A very small percentage mentioned domestic violence (Lorenzen, 2017, p. 75).
} 
There is, therefore, no consensus on the primacy of either violence or economic factors. The inconsistency of the findings may in part be due to challenges in collecting accurate and reliable answers to questions about motivations for migration. Some sources highlight the difficulties that children may have in articulating the causes for their migration (UNHCR, 2014a, pp. 20-21). For one, they may not fully understand why they are migrating if their parents made the decision for them (Lorenzen, 2017, p. 754). Further, children may be reluctant to discuss experiences that have caused them shame or trauma, such as sexual abuse (KIND \& HRCFMC, 2017, p. 10), especially with strangers they do not yet trust (Khashu, 2010, p. 24) or with interviewers of the opposite sex (UNHCR, 2014b, p. 36). In addition, children may have normalized domestic abuse to the point of not recognizing it, because "it is all they have known" (UNHCR, 2014a, p. 28). ${ }^{26}$

Moreover, a single response may potentially encompass both economic conditions and violence: When a child states that they have migrated to "seek a better life," they may be referring simultaneously to the need to flee violence and to the wish to seek better socioeconomic conditions (Lorenzen, 2017, p. 762). Similarly, some children may only state that they are looking for better educational opportunities and omit to mention that it was gang members who prevented them from attending school (Clemens, 2017, p. 6). Conversely, children may name violence as the cause of their migration because they believe it will improve their chances of staying in the destination country (Clemens, 2017, p. 6).

Correlative evidence is immune from these particular limitations. The next subsection will examine whether it paints a more coherent picture of the relative weight of economic factors

\footnotetext{
${ }^{26}$ Schmidt (2017b) elaborates on an observation first made in the UNHCR (2014a) study in the United States: Participants who experience abuse may not always explicitly identify it as a cause for migration. Only 22 of the 77 children who disclosed surviving abuse in the home initially named it as a cause for their migration, and 13 cited it in response to follow up questions. Forty-two mentioned it another point of the interview, but never linked it to their migration (p. 60).
} 
and violence.

\subsection{Correlative evidence}

Jones (2017) found a stronger correlation, in Honduras, between migration and homicide rates than between migration and the unemployment rate (p. 354). However, when he added to the mix economic (and political) factors in the United States, he found that employment in the destination country was more closely related to migration rates than unemployment or violence in the NTCA countries (p. 349). These results therefore do not break the tie between economic factors and violence.

Clemens (2017), for his part, tested the relative importance of the homicide rate, poverty rate and income per capita at the municipal level in the countries of origin. He concluded that the homicide rate on its own and in combination with economic factors explained as much of the migration as economic indicators alone (p. 22). Although Clemens (2017) uses these data to demonstrate the power of factors related to violence, the importance of economic factors in his model should not be downplayed.

The correlative evidence therefore does not settle the argument about the relative weight of economic factors and violence in the decision calculus of unaccompanied children and their families any more conclusively than did the data from migrant children. The insights of Orozco and Yansura's (2014) adult respondents may provide a key to interpreting these findings. Thirtysix percent named violence and twenty-nine percent the absence of economic opportunities as the main cause for the migration of unaccompanied children, but many of them mentioned both factors "in quick succession, rather than [stating] one as unequivocally being the [main] cause" (p. 15). This intuition is confirmed by scholars, who conclude that economic factors and violence, both in and outside the home, are interrelated (UNHCR, 2014b, p. 38), "inextricably 
linked" - in the words of Schmidt (2017a, p. 62)—and mutually reinforcing (Hurtado Paz y Paz et al., 2015, p. 153). The next subsection will explore these connections in more detail.

\subsection{The interrelatedness of violence and economic factors}

Poor economic conditions create a favourable environment for violence in several ways (Clemens, 2017, p. 4; Stinchcomb \& Hershberg, 2014, p. 17). In the absence of decent employment opportunities for youth, or in contexts of widespread food insecurity, gang membership and the sources of income it offers—-such as extortion, robbery, kidnapping, and trafficking - may become an attractive option (Orozco \& Yansura, 2014, p. 16; WFP \& IOM, 2016, pp. 15-16). A 17-year-old Salvadoran participant quoted in Schmidt (2017a) verbalizes this relationship:

Gangs are increasing because of the economy, because there aren't enough jobs. Kids think it's better to rob and steal because they don't see any other way to make money. (p. 64)

As a consequence, children suffering from economic deprivation are vulnerable to being recruited by gangs (Jaimez, 2017, p. 12). In addition, Schmidt (2017a) contends that youth who neither work nor study are likelier to join gangs "due to idle or unsupervised time" (p. 64), a view shared by Oppenheimer (2014). Moreover, economic conditions are linked to violence inside the home, as well. According to Stinchcomb and Hershberg (2014), "male heads of household, frustrated by the inability to generate income sufficient to satisfy even the most minimal necessities for household survival, become aggressors not only in the public sphere but in the private one as well" (p. 21).

Economic factors also lead to violence in more indirect ways. Parental absence due to economic migration has been argued to constitute, on the one hand, a risk factor for gang 
membership (Jaimez, 2017, p. 9; Lorenzen, 2017, p. 758; Stinchcomb \& Hershberg, 2014, p. 22), and on the other, a cause for extortion, because children who receive remittances from parents are perceived as being better off (Kandel et al., 2015). Further, the children left behind are also more vulnerable to abuse from their surrogate caretakers (Lorenzen, 2017, p. 758; Stinchcomb \& Hershberg, 2014, p. 455).

However, not only do poor economic conditions foster violence, but violence, in turn, also degrades economic conditions. Generalized violence is reported to inhibit economic growth and opportunity creation (Clemens, 2017). Gang violence disfavours foreign investment (GAO, 2015, p. 4), and gang members target small business owners for extortion (Torres, 2017, p. 7; Stinchcomb \& Hershberg, 2014, p. 19). Gang violence also increases food insecurity: members assault people for their food stamps, and attack customers and sellers at public markets (WFP \& IOM, 2016, p. 26). Finally, as discussed earlier, gang activity also acts as a barrier to education for many children whose classmates try to recruit them or who are harassed on their way to and from school (Jaimez, 2017, pp. 23-24; Lorenzen, 2017, pp. 757-758; Machín Álvarez, 2015, p. 401; Stinchcomb \& Hirshberg, 2014, p. 17).

Ultimately, poor economic conditions and violence form a vicious cycle in which they breed and compound each other, as illustrated in Figure 3.

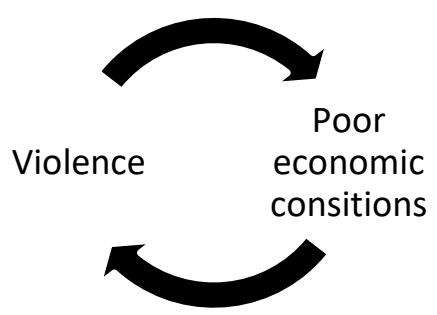

Figure 3. Vicious cycle of violence and poor economic conditions in the NTCA 
Unaccompanied children are thus not migrating in response to either violence or economic factors in isolation; they migrate because of violence that is produced by poor economic conditions, and because of economic conditions that have deteriorated due to violence. I therefore propose that, in the case of unaccompanied children from the NTCA, violence and economic conditions should be understood as a single, complex cause for migration.

\section{Migration as a solution for survival}

Unaccompanied children from the NTCA defy the compartmentalization of economic and protection-related factors that underpins traditional models of migration, because their survival in their country of origin is threatened by a compound of violence and poor economic conditions. Thus, even when they name economic factors only, unaccompanied children should not be thought of as voluntary migrants. Rather, as argued by Jaimez (2017), they provide an excellent case study of Betts's (2013) concept of survival migration. Betts defined survival migrants as "persons who are outside their country of origin because of an existential threat for which they have no access to a domestic remedy or resolution" (p. 23). Indeed, unaccompanied children from the NTCA are migrating in order to satisfy their basic rights and needs - that is, in order to remedy a threat to their very existence-which their countries of origin are "unable or unwilling” to meet (Stinchcomb \& Hershberg, 2014, p. 25; see also Gatica López, 2016; Nichols et al., 2017, p. 1975-1976; UNHCR, 2014a).

The vulnerability of unaccompanied children to threats to their subsistence and physical integrity does not, however, preclude agency. Indeed, child migrants and their families avail themselves of existing resources and enabling factors to find a solution to the desperate conditions in the country of origin (Ceriani Cernadas, 2012, p. 14; Gaborit et al, 2015, p. 203; 
Jaimez, 2017, p. 12; Schmidt, 2017a, p. 73). Many parents make the decision for their children to migrate (Cajina \& Orozco, 2016, p. 4; Casa Alianza Honduras et al., 2016, pp. 15, 29; Robles, 2014; UNHCR, 2014b, p. 44), but in some cases it is the children themselves, especially the older ones, who are choosing to leave (Hurtado Paz y Paz et al., 2015, p. 156), sometimes without even consulting their families (Khashu, 2010, p. 17, 28; Nichols et al., 2017, p. 1979). This is consistent with the view, advocated in the literature on unaccompanied child migrants, that children are capable of making decisions to improve their life conditions (see in particular O'Higgins, 2012, p. 82). Becker Herbst et al. (2018) argue that migration is an act of resilience through which unaccompanied children respond to inadequate material resources and unsupportive relationships. To Varela Huerta (2015), the migration of unaccompanied children represents no less than a form of collective action against the state's unwillingness to protect from violence or to deliver better socioeconomic conditions (p. 29).

Schmidt (2017a) has described the options available to youth in the NTCA as "no-win" situations (p. 64): They can either put up with the lack of decent opportunities to earn a living, or join a gang. Within this framework, migration is a quest for a third option, and an affirmation of their right to a dignified life. 


\section{CHAPTER 5. CONCLUSION.}

This MRP set out to answer three research questions. The main one was: "What are the factors driving the migration of unaccompanied children from the NTCA?" The two subsidiary ones were: "Are unaccompanied children from the NTCA motivated chiefly by push or pull factors?" and "Are unaccompanied children from the NTCA primarily migrating for economic reasons, to flee from violence, or because of a combination of the two factors?"

Following a scoping review guided by grounded theory principles, I conclude that the migration of unaccompanied children from the NTCA is driven by four major factors: violence in the country of origin; desperate economic conditions; parental absence resulting in either a desire for family reunification or in family breakdown; and, for the children migrating to the United States, perceptions of ease of entry into the destination country. Among these drivers, violence and economic conditions - the push factors - are causes of the migration flow, while family reunification and the perception of ease of entry to the United States - the pull factorsact as enabling circumstances.

It is virtually impossible to disentangle the relative importance of violence and economic conditions based on the data reported in the sampled studies. Moreover, these two factors form a vicious cycle whereby they mutually compound each other. Unaccompanied children from the NTCA thereby fit neither the economic-migrant nor the protection-seeker profile. Their migration is better explained by a framework such as Betts's (2013) survival migration, in which migrants seek remedy to threats to subsistence and life by crossing one or several borders.

The scoping review has revealed some gaps in the current literature that represent avenues for future research. First, there are few sources examining the migration of children to countries other than Mexico and, especially, the United States. Consequently, it is unclear what 
pull factors might operate in those cases. Second, as pointed out in the section about demographic characteristics, the migration decisions of youth who are members of sexual and ethnic minorities are rarely discussed, in part due to the difficulty in accessing relevant data. For example, it has been noted that Afro-descendant children from Garifuna communities in northern Honduras participate in unaccompanied child migration (Stark, Shapiro, de la Pena, \& Ajl, 2015), but the causes of their migration have not been explored. Finally, the interest in migration from the NTCA sparked by family separations at the U.S.-Mexico border in the spring and early summer of 2018 (e.g., Shear, Goodnough, \& Haberman, 2018) warrants a comparison of the drivers of migration for unaccompanied children, families, and single adults from the NTCA.

Due to time and space constraints, I have not been able to do justice to some of the themes developed in the sources in my sample. Topics that deserve further attention include the role of existing migration networks (e.g., Rodriguez et al., 2017, p. 11) and of knowledge about the risks of the journey in the decision calculus (Hiskey et al., 2016). There is also an emergent literature assessing the effectiveness of some of the initiatives put in place to stem the flow of migration. For example, Roth \& Hartnett (2018) investigate the impact of centres for at-risk youth in neighbourhoods with gang activity in El Salvador.

I would be remiss not to mention that the decision to migrate is but the first chapter in a harrowing journey to the destination country. While they are in transit, unaccompanied children are vulnerable to rape, robbery, severe injuries from falling off cargo trains, and even murder (Becker Herbst et al. 2018, p. 242; Ceballos Castañeda \& Del Carpio Ovando, 2015, p. 1464; Nazario, 2006; UNHCR, 2014b, caption p. 32). Once they arrive in the destination country, they must learn how to navigate the asylum system (Medrano, 2017). If they are deported (as were the participants in Casa Alianza Honduras et al., 2016; Hurtado Paz y Paz, 2015; Kennedy, 2014; 
Rivera et al., 2015, among others), they must decide whether to reintegrate into their community of origin, or whether to leave again. Each stage of this journey deserves its own MRP. 


\section{APPENDIX: LIST OF SOURCES INCLUDED IN SCOPING REVIEW SAMPLE}

(full bibliographical information cited in the References section)

\begin{tabular}{|c|c|c|c|c|}
\hline Title & Author & Year & $\begin{array}{l}\text { Main source of } \\
\text { evidence }\end{array}$ & $\begin{array}{l}\text { Source } \\
\text { type }\end{array}$ \\
\hline $\begin{array}{l}\text { Violencia infantil: La experiencia de } \\
\text { niños y jóvenes indocumentados } \\
\text { cruzando la frontera entre México y } \\
\text { los Estados Unidos }\end{array}$ & Cao, $\mathrm{M}$. & 2017 & $\begin{array}{l}\text { Unaccompanied } \\
\text { children/other } \\
\text { stakeholders } \\
\text { (via newspaper } \\
\text { articles) } \\
\end{array}$ & Thesis \\
\hline $\begin{array}{l}\text { Wave of Minors on Their Own Rush } \\
\text { to Cross Southwest Border }\end{array}$ & Robles, F. & 2014 & $\begin{array}{l}\text { Unaccompanied } \\
\text { children/other } \\
\text { stakeholders } \\
\end{array}$ & $\begin{array}{l}\text { Newspaper } \\
\text { article }\end{array}$ \\
\hline $\begin{array}{l}\text { Misperceptions of U.S. Policy Key } \\
\text { Driver in Central American Migrant } \\
\text { Surge }\end{array}$ & $\begin{array}{l}\text { El Paso } \\
\text { Intelligence } \\
\text { Center } \\
\end{array}$ & 2014 & $\begin{array}{l}\text { Unaccompanied } \\
\text { children/other } \\
\text { stakeholders } \\
\end{array}$ & $\begin{array}{l}\text { Policy } \\
\text { report }\end{array}$ \\
\hline $\begin{array}{l}\text { Children in Transit: Results of } \\
\text { Interviews with Central American } \\
\text { Unaccompanied } \\
\text { Encountered in Mexico }\end{array}$ & Khashu, A. & 2010 & $\begin{array}{l}\text { Unaccompanied } \\
\text { children }\end{array}$ & $\begin{array}{l}\text { NGO } \\
\text { report }\end{array}$ \\
\hline $\begin{array}{l}\text { Forced From Home: The Lost Boys } \\
\text { and Girls of Central America }\end{array}$ & $\begin{array}{l}\text { Women's } \\
\text { Refugee } \\
\text { Commission }\end{array}$ & 2012 & $\begin{array}{l}\text { Unaccompanied } \\
\text { children }\end{array}$ & $\begin{array}{l}\text { NGO } \\
\text { report }\end{array}$ \\
\hline Arrancados de raíz & $\begin{array}{l}\text { United Nations } \\
\text { High } \\
\text { Commission } \\
\text { for Refugees }\end{array}$ & 2014 & $\begin{array}{l}\text { Unaccompanied } \\
\text { children }\end{array}$ & $\begin{array}{l}\text { NGO } \\
\text { report }\end{array}$ \\
\hline $\begin{array}{l}\text { "Quiero ayudar a mi mamá" ["I want } \\
\text { to help my mom"] }\end{array}$ & Loya, J. & 2014 & $\begin{array}{l}\text { Unaccompanied } \\
\text { children }\end{array}$ & $\begin{array}{l}\text { Newspaper } \\
\text { article }\end{array}$ \\
\hline "Salí para no ser asesinado" & Martín, F. & 2014 & $\begin{array}{l}\text { Unaccompanied } \\
\text { children }\end{array}$ & $\begin{array}{l}\text { Newspaper } \\
\text { article }\end{array}$ \\
\hline "Sin nada, me tiré a la calle" & $\begin{array}{l}\text { El Universal } \\
\text { newspaper }\end{array}$ & 2014 & $\begin{array}{l}\text { Unaccompanied } \\
\text { children }\end{array}$ & $\begin{array}{l}\text { Newspaper } \\
\text { article }\end{array}$ \\
\hline $\begin{array}{l}\text { Children on the Run. } \\
\text { Unaccompanied Children Leaving } \\
\text { Central America and Mexico and the } \\
\text { Need for International Protection }\end{array}$ & $\begin{array}{l}\text { United Nations } \\
\text { High } \\
\text { Commission } \\
\text { for Refugees } \\
\end{array}$ & 2014 & $\begin{array}{l}\text { Unaccompanied } \\
\text { children }\end{array}$ & $\begin{array}{l}\text { NGO } \\
\text { report }\end{array}$ \\
\hline $\begin{array}{l}\text { No Childhood Here. Why Central } \\
\text { American Children Are Fleeing } \\
\text { Their Homes. }\end{array}$ & $\mathrm{y}, \mathrm{E}$. & 2014 & $\begin{array}{l}\text { Unaccompanied } \\
\text { children }\end{array}$ & $\begin{array}{l}\text { Policy } \\
\text { report }\end{array}$ \\
\hline $\begin{array}{l}\text { Andares tempranos. Estrategias de } \\
\text { movilidad de adolescentes "no } \\
\text { acompañados" en la frontera } \\
\text { México-Estados Unidos }\end{array}$ & $\begin{array}{l}\text { Silva } \\
\text { Hernández, A. } \\
\text { L. }\end{array}$ & 2014 & $\begin{array}{l}\text { Unaccompanied } \\
\text { children }\end{array}$ & Thesis \\
\hline Honduras & Rivera, L. G., & 2015 & Unaccompanied & NGO \\
\hline
\end{tabular}




\begin{tabular}{|c|c|c|c|c|}
\hline Title & Author & Year & $\begin{array}{l}\text { Main source of } \\
\text { evidence }\end{array}$ & $\begin{array}{l}\text { Source } \\
\text { type }\end{array}$ \\
\hline & $\begin{array}{l}\text { Ruelas, J. G., } \\
\text { Herrera Cuello, } \\
\text { U., Flores, J., } \\
\text { \& Flores Pinto, } \\
\text { C. }\end{array}$ & & children & report \\
\hline Guatemala & $\begin{array}{l}\text { Hurtado Paz y } \\
\text { Paz, Girón } \\
\text { Solózano, C. } \\
\text { L., \& Ibarra } \\
\text { González, G. }\end{array}$ & 2015 & $\begin{array}{l}\text { Unaccompanied } \\
\text { children }\end{array}$ & $\begin{array}{l}\text { NGO } \\
\text { report }\end{array}$ \\
\hline $\begin{array}{l}\text { Niñas y niños migrantes: Factores de } \\
\text { expulsión y desafíos para su } \\
\text { reinserción en Honduras }\end{array}$ & $\begin{array}{l}\text { Casa Alianza } \\
\text { Honduras, de } \\
\text { Pastoral d } \\
\text { Movilidad } \\
\text { Humana \& } \\
\text { Catholic Relief } \\
\text { Services } \\
\end{array}$ & 2016 & $\begin{array}{l}\text { Unaccompanied } \\
\text { children }\end{array}$ & $\begin{array}{l}\text { NGO } \\
\text { report }\end{array}$ \\
\hline $\begin{array}{l}\text { Características, tendencias y causas } \\
\text { de la migración de niñas, niños y } \\
\text { adolescentes desde, hacia y en } \\
\text { tránsito por México, 2011-2016 }\end{array}$ & $\begin{array}{l}\text { Lorenzen, M. } \\
\mathrm{J} .\end{array}$ & 2016 & $\begin{array}{l}\text { Unaccompanied } \\
\text { children }\end{array}$ & $\begin{array}{l}\text { Scholarly } \\
\text { paper }\end{array}$ \\
\hline $\begin{array}{l}\text { Migración de niñas, niños y } \\
\text { adolescentes: } \\
\text { análisis de información de la Red de } \\
\text { módulos y albergues de los Sistemas } \\
\text { DIF, 2007-2016 }\end{array}$ & \begin{tabular}{|l} 
Consejo \\
Nacional de \\
Población
\end{tabular} & 2016 & $\begin{array}{l}\text { Unaccompanied } \\
\text { children }\end{array}$ & $\begin{array}{l}\text { NGO } \\
\text { report }\end{array}$ \\
\hline $\begin{array}{l}\text { Childhood Cut Short: Sexual and } \\
\text { Gender-based Violence Against } \\
\text { Central American Migrant and } \\
\text { Refugee Children }\end{array}$ & $\begin{array}{lr}\text { Kids in } & \text { Need } \\
\text { of Defense \& } \\
\text { Human } & \text { Rights } \\
\text { Center } & \text { Fray } \\
\text { Matías } & \text { de } \\
\text { Córdova } & \\
\end{array}$ & 2017 & $\begin{array}{l}\text { Unaccompanied } \\
\text { children }\end{array}$ & $\begin{array}{l}\text { NGO } \\
\text { report }\end{array}$ \\
\hline $\begin{array}{l}\text { The Exclusion of Central American } \\
\text { Minors (UMC) Under the Refugee } \\
\text { Regime in the United States }\end{array}$ & Jaimez, Daisy & 2017 & $\begin{array}{l}\text { Unaccompanied } \\
\text { children }\end{array}$ & Thesis \\
\hline $\begin{array}{l}\text { Child Maltreatment and Child } \\
\text { Migration: What Unaccompanied } \\
\text { Migrant Children from Central } \\
\text { America and Mexico Say About } \\
\text { Abuse and Neglect and Its } \\
\text { Implications for Post-Migration } \\
\text { Practice }\end{array}$ & Schmidt, S. G. & 2017 & $\begin{array}{l}\text { Unaccompanied } \\
\text { children }\end{array}$ & $\begin{array}{l}\text { Scholarly } \\
\text { paper }\end{array}$ \\
\hline \begin{tabular}{lrrr} 
The Mixed & \multicolumn{2}{c}{ Motives of } \\
Unaccompanied & Child $\quad$ Migrants
\end{tabular} & Lorenzen, M. & 2017 & $\begin{array}{l}\text { Unaccompanied } \\
\text { children }\end{array}$ & $\begin{array}{l}\text { Scholarly } \\
\text { paper }\end{array}$ \\
\hline
\end{tabular}




\begin{tabular}{|c|c|c|c|c|}
\hline Title & Author & Year & $\begin{array}{l}\text { Main source of } \\
\text { evidence }\end{array}$ & $\begin{array}{l}\text { Source } \\
\text { type }\end{array}$ \\
\hline \multicolumn{5}{|l|}{$\begin{array}{l}\text { from Central America's Northern } \\
\text { Triangle }\end{array}$} \\
\hline $\begin{array}{l}\text { "They Need to Give Us a Voice": } \\
\text { Lessons from Listening to } \\
\text { Unaccompanied Central American } \\
\text { and Mexican Children on Helping } \\
\text { Children Like Themselves }\end{array}$ & Schmidt, S. & 2017 & $\begin{array}{l}\text { Unaccompanied } \\
\text { children }\end{array}$ & $\begin{array}{l}\text { Scholarly } \\
\text { paper }\end{array}$ \\
\hline $\begin{array}{l}\text { Unaccompanied Refugee Minors } \\
\text { from Central America: } \\
\text { Understanding Their Journey and } \\
\text { Implications for Counselors }\end{array}$ & $\begin{array}{l}\text { Tello, A. M., } \\
\text { Castellon, N. } \\
\text { E., Aguilar, A. } \\
\text { \& Sawyer, C. } \\
\text { B. }\end{array}$ & 2017 & $\begin{array}{l}\text { Unaccompanied } \\
\text { children }\end{array}$ & $\begin{array}{l}\text { Scholarly } \\
\text { paper }\end{array}$ \\
\hline $\begin{array}{l}\text { "They Were Going to Kill Me": } \\
\text { Resilience in Unaccompanied } \\
\text { Immigrant Migrants }\end{array}$ & $\begin{array}{l}\text { Becker-Herbst, } \\
\text { R, Sabet, R. F., } \\
\text { Swanson, A., } \\
\text { Suarez, L. G., } \\
\text { Marques, D. } \\
\text { S., Ameen, E. } \\
\text { J., \& } \\
\text { Aldarondo, E. }\end{array}$ & 2018 & $\begin{array}{l}\text { Unaccompanied } \\
\text { children }\end{array}$ & $\begin{array}{l}\text { Scholarly } \\
\text { paper }\end{array}$ \\
\hline $\begin{array}{l}\text { Creating Reasons to Stay? } \\
\text { Unaccompanied Youth Migration, } \\
\text { Community-based Programs, and the } \\
\text { Power of "Push" Factors in El } \\
\text { Salvador }\end{array}$ & $\begin{array}{l}\text { Roth, B. J., \& } \\
\text { Hartnett, C. S. }\end{array}$ & 2018 & $\begin{array}{l}\text { Unaccompanied } \\
\text { children }\end{array}$ & $\begin{array}{l}\text { Scholarly } \\
\text { paper }\end{array}$ \\
\hline $\begin{array}{l}\text { Niñez detenida. Los derechos de los } \\
\text { niños, niñas y adolescentes } \\
\text { migrantes en la frontera México- } \\
\text { Guatemala }\end{array}$ & $\begin{array}{l}\text { Ceriani } \\
\text { Cernadas, } \mathrm{P} \text {. }\end{array}$ & 2012 & Other studies & $\begin{array}{l}\text { NGO } \\
\text { report }\end{array}$ \\
\hline $\begin{array}{l}\text { Dramatic Surge in the Arrival of } \\
\text { Unaccompanied Children Has Deep } \\
\text { Roots and No Simple Solutions }\end{array}$ & $\begin{array}{l}\text { Chishti, M. \& } \\
\text { Hipsman, F. }\end{array}$ & 2014 & Other studies & $\begin{array}{l}\text { Policy } \\
\text { report }\end{array}$ \\
\hline $\begin{array}{l}\text { Unaccompanied Migrant } \\
\text { from Children } \\
\text { Causes, and Responses }\end{array}$ & $\begin{array}{l}\text { Stinchcomb, } \\
\text { D. \& } \\
\text { Hershberg, E. }\end{array}$ & 2014 & Other studies & $\begin{array}{l}\text { Policy } \\
\text { report }\end{array}$ \\
\hline $\begin{array}{l}\text { The Child Migrant Crisis Is Just the } \\
\text { Latest Disastrous Consequence of } \\
\text { America's Drug War }\end{array}$ & $\begin{array}{l}\text { Carpenter, } \mathrm{T} \text {. } \\
\mathrm{G} \text {. }\end{array}$ & 2014 & Other st & $\begin{array}{l}\text { Newspaper } \\
\text { article }\end{array}$ \\
\hline $\begin{array}{l}\text { Stronger Neighbors - Stronger } \\
\text { Borders: Addressing the Root } \\
\text { Causes of the Migration Surge from } \\
\text { Central America }\end{array}$ & U.S. Senate & 2015 & Other studies & $\begin{array}{l}\text { Policy } \\
\text { report }\end{array}$ \\
\hline El Salvador & $\begin{array}{l}\text { Gaborit, M., } \\
\text { Zetino Duarte, }\end{array}$ & 2015 & Other studies & $\begin{array}{l}\text { Policy } \\
\text { report }\end{array}$ \\
\hline
\end{tabular}




\begin{tabular}{|c|c|c|c|c|}
\hline Title & Author & Year & $\begin{array}{l}\text { Main source of } \\
\text { evidence }\end{array}$ & $\begin{array}{l}\text { Source } \\
\text { type }\end{array}$ \\
\hline & $\begin{array}{l}\text { M., Orellana, } \\
\text { C. I., \& Brioso, } \\
\text { L. }\end{array}$ & & & \\
\hline $\begin{array}{l}\text { The Child and Family Migration } \\
\text { Surge of Summer 2014: A Short- } \\
\text { Lived Crisis With a Lasting Impact }\end{array}$ & $\begin{array}{l}\text { Chishti, M. \& } \\
\text { Hipsman, F. }\end{array}$ & 2015 & Other studies & $\begin{array}{l}\text { Scholarly } \\
\text { paper }\end{array}$ \\
\hline $\begin{array}{l}\text { Unaccompanied Alien Journey: } \\
\text { Potential Factors Contributing to } \\
\text { Recent Immigration }\end{array}$ & $\begin{array}{l}\text { Kandel, W. A., } \\
\text { Bruno, A., } \\
\text { Meyer, P. J., } \\
\text { Seelke, C. R., } \\
\text { Taft-Morales, } \\
\text { M., \& Wasem, } \\
\text { R. E. } \\
\end{array}$ & 2015 & Other studies & $\begin{array}{l}\text { Scholarly } \\
\text { paper }\end{array}$ \\
\hline $\begin{array}{l}\text { Menores y migración: un } \\
\text { acercamiento a los tipos de violencia } \\
\text { en Centroamérica con énfasis en los } \\
\text { y las menores migrantes no } \\
\text { acompañados }\end{array}$ & $\begin{array}{l}\text { Machín } \\
\text { Álvarez, M. }\end{array}$ & 2015 & Other studies & $\begin{array}{l}\text { Scholarly } \\
\text { paper }\end{array}$ \\
\hline $\begin{array}{l}\text { Las } \text { Tres Caras de Herodes: Éxodo } \\
\text { de Criaturas, Migraciones } \\
\text { Catastróficas y Vida en Sombras }\end{array}$ & $\begin{array}{l}\text { Suárez- } \\
\text { Orozco, M. }\end{array}$ & 2015 & Other studies & $\begin{array}{l}\text { Scholarly } \\
\text { paper }\end{array}$ \\
\hline $\begin{array}{l}\text { Unaccompanied Child Migration to } \\
\text { the United States. The Tension } \\
\text { Between Protection and Prevention }\end{array}$ & $\begin{array}{l}\text { Rosenblum, M. } \\
\text { R. }\end{array}$ & 2015 & Other studies & $\begin{array}{l}\text { Policy } \\
\text { report }\end{array}$ \\
\hline $\begin{array}{ll} & \text { "Buscando una vida vivible": la } \\
\text { migración forzada de niños de } \\
\text { Centroamérica como práctica de } \\
\text { fuga de la "muerte en vida" }\end{array}$ & $\begin{array}{l}\text { Varela Huerta, } \\
\text { A. }\end{array}$ & 2015 & Other studies & $\begin{array}{l}\text { Scholarly } \\
\text { paper }\end{array}$ \\
\hline $\begin{array}{l}\text { Estructura y agencia en la migración } \\
\text { infantil centroamericana }\end{array}$ & $\begin{array}{l}\text { Acuña } \\
\text { González, G. } \\
\text { E. }\end{array}$ & 2016 & Other studies & $\begin{array}{l}\text { Scholarly } \\
\text { paper }\end{array}$ \\
\hline $\begin{array}{l}\text { U.S. Policies Drive Migration from } \\
\text { Central America }\end{array}$ & Bacon, D. & 2016 & Other studies & $\begin{array}{l}\text { Newspaper } \\
\text { article }\end{array}$ \\
\hline $\begin{array}{l}\text { Falacias y realidades de una crisis } \\
\text { humanitaria y política. Menores } \\
\text { centroamericanos que migran en } \\
\text { busca del "sueño americano" }\end{array}$ & $\begin{array}{l}\text { Cajina, R. \& } \\
\text { Orozco, L. }\end{array}$ & 2016 & Other studies & $\begin{array}{l}\text { Scholarly } \\
\text { paper }\end{array}$ \\
\hline $\begin{array}{l}\text { Niñez migrante desde } \\
\text { Centroamérica: los rostros de la baja } \\
\text { inversión social pública }\end{array}$ & $\begin{array}{l}\text { Gatica López, } \\
\text { G. A. }\end{array}$ & 2016 & Other studies & $\begin{array}{l}\text { Scholarly } \\
\text { paper }\end{array}$ \\
\hline $\begin{array}{l}\text { Trends in Unaccompanied Child and } \\
\text { Family Migration in Central } \\
\text { America }\end{array}$ & $\begin{array}{l}\text { Rosenblum, M. } \\
\text { R. \& Ball, I. }\end{array}$ & 2016 & Other studies & $\begin{array}{l}\text { Policy } \\
\text { report }\end{array}$ \\
\hline American & Chishti, M. \& & 2016 & Other studies & Policy \\
\hline
\end{tabular}




\begin{tabular}{|c|c|c|c|c|}
\hline Title & Author & Year & $\begin{array}{l}\text { Main source of } \\
\text { evidence }\end{array}$ & $\begin{array}{l}\text { Source } \\
\text { type }\end{array}$ \\
\hline $\begin{array}{l}\text { Migration to the United States May } \\
\text { Prove an Enduring Phenomenon }\end{array}$ & Hipsman, F. & & & report \\
\hline $\begin{array}{l}\text { Violencia, frontera sur y niñez } \\
\text { migrante }\end{array}$ & $\begin{array}{l}\text { Ceballos } \\
\text { Castañeda, U. } \\
\text { \& Del Carpio } \\
\text { Ovando, P. S. }\end{array}$ & 2017 & Other studies & $\begin{array}{l}\text { Scholarly } \\
\text { paper }\end{array}$ \\
\hline $\begin{array}{l}\text { Seeking a Rational Approach to a } \\
\text { Regional Refugee Crisis: Lessons } \\
\text { from the Summer 2014 "Surge" of } \\
\text { Central American Women and } \\
\text { Children at the US-Mexico Border }\end{array}$ & $\begin{array}{l}\text { Musalo, K. \& } \\
\text { Lee, E. }\end{array}$ & 2017 & Other studies & $\begin{array}{l}\text { Scholarly } \\
\text { paper }\end{array}$ \\
\hline $\begin{array}{l}\text { Unaccompanied Minors from the } \\
\text { Northern Central American } \\
\text { Countries in the Migrant Stream: } \\
\text { Social Differentials and Institutional } \\
\text { Contexts }\end{array}$ & $\begin{array}{l}\text { Rodriguez, N., } \\
\text { Urrutia-Rojas, } \\
\text { X, \& } \\
\text { Gonzalez, L.G. }\end{array}$ & 2017 & Other studies & $\begin{array}{l}\text { Scholarly } \\
\text { paper }\end{array}$ \\
\hline $\begin{array}{l}\text { Understanding Central American } \\
\text { Migration: The Crisis of Central } \\
\text { American Child Migrants in Context }\end{array}$ & $\begin{array}{l}\text { Orozco, M. \& } \\
\text { Yansura, J. }\end{array}$ & 2014 & $\begin{array}{l}\text { Other } \\
\text { stakeholders/ } \\
\text { correlative }\end{array}$ & $\begin{array}{l}\text { Policy } \\
\text { report }\end{array}$ \\
\hline $\begin{array}{l}\text { Hunger Without Borders. The } \\
\text { Hidden Links Between Food } \\
\text { Insecurity, Violence and Migration } \\
\text { in the Northern Triangle of Central } \\
\text { America }\end{array}$ & $\begin{array}{l}\text { United Nations } \\
\text { World Food } \\
\text { Programme \& } \\
\text { International } \\
\text { Organization } \\
\text { for Migration }\end{array}$ & 2016 & $\begin{array}{l}\text { Other } \\
\text { stakeholders/ } \\
\text { correlative }\end{array}$ & $\begin{array}{l}\text { NGO } \\
\text { report }\end{array}$ \\
\hline $\begin{array}{l}\text { Migrants Flow in South Texas, as } \\
\text { Do Rumors }\end{array}$ & Preston, J. & 2014 & $\begin{array}{l}\text { Other } \\
\text { stakeholders }\end{array}$ & $\begin{array}{l}\text { Newspaper } \\
\text { article }\end{array}$ \\
\hline EU se equivoca con niños migrantes & $\begin{array}{l}\text { Oppenheimer, } \\
\text { A. }\end{array}$ & 2014 & $\begin{array}{l}\text { Other } \\
\text { stakeholders }\end{array}$ & \begin{tabular}{|l} 
Newspaper \\
article
\end{tabular} \\
\hline $\begin{array}{l}\text { Don't Blame Central American } \\
\text { Newspapers for Influx of } \\
\text { Undocumented Children }\end{array}$ & Planas, R. & 2014 & $\begin{array}{l}\text { Other } \\
\text { stakeholders }\end{array}$ & $\begin{array}{l}\text { Newspaper } \\
\text { article }\end{array}$ \\
\hline $\begin{array}{l}\text { Central America. Information on } \\
\text { Migration of Unaccompanied } \\
\text { Children from El Salvador, } \\
\text { Guatemala, and Honduras }\end{array}$ & $\begin{array}{l}\text { U.S. } \\
\text { Government } \\
\text { Accountability } \\
\text { Office } \\
\end{array}$ & 2015 & $\begin{array}{l}\text { Other } \\
\text { stakeholders }\end{array}$ & $\begin{array}{l}\text { Policy } \\
\text { report }\end{array}$ \\
\hline $\begin{array}{l}\text { Transnational Information Politics } \\
\text { and the "Child Migration Crisis": } \\
\text { Guatemalan NGOs Respond to } \\
\text { Youth Migration }\end{array}$ & $\begin{array}{l}\text { Nichols, B., } \\
\text { Umana, K, } \\
\text { Britton, T., } \\
\text { Farias, L., } \\
\text { Lavalley, \& } \\
\text { Hall-Clifford, } \\
\text { R. }\end{array}$ & 2017 & $\begin{array}{l}\text { Other } \\
\text { stakeholders }\end{array}$ & $\begin{array}{l}\text { Scholarly } \\
\text { paper }\end{array}$ \\
\hline Understanding The Causes of & \begin{tabular}{|l|} 
Torres, E. \\
\end{tabular} & 2017 & Other & Thesis \\
\hline
\end{tabular}




\begin{tabular}{|l|l|l|l|l|}
\hline Title & Author & Year & $\begin{array}{l}\text { Main source of } \\
\text { evidence }\end{array}$ & $\begin{array}{l}\text { Source } \\
\text { type }\end{array}$ \\
\hline $\begin{array}{l}\text { Unaccompanied Minors Migrating to } \\
\text { the US During 2014 }\end{array}$ & & stakeholders & \\
\hline $\begin{array}{l}\text { Children's Migration to the United } \\
\text { States from Mexico and Central } \\
\text { America: Evidence from the } \\
\text { Mexican and Latin American } \\
\text { Migration Projects }\end{array}$ & $\begin{array}{l}\text { Donato, K. \& } \\
\text { Sisk, B. }\end{array}$ & 2015 & Correlative & $\begin{array}{l}\text { Scholarly } \\
\text { paper }\end{array}$ \\
\hline $\begin{array}{l}\text { DACA and the Surge in } \\
\text { Unaccompanied Minors at the US- }\end{array}$ & $\begin{array}{l}\text { Amuedo- } \\
\text { Dorantes, C. \& } \\
\text { Pexico Border Cuttitanun, T. }\end{array}$ & 2016 & Correlative & $\begin{array}{l}\text { Scholarly } \\
\text { paper }\end{array}$ \\
\hline $\begin{array}{l}\text { The Central American Child } \\
\text { Migration Surge: A Temporal And }\end{array}$ & & & & Scholarly \\
Spatial Investigation Of Its Causes & Jones, R. C. & 2017 & Correlative & paper \\
\hline $\begin{array}{l}\text { Violence, Development, and } \\
\text { Migration Waves: Evidence from } \\
\text { Central American Child Migrant } \\
\text { Apprehensions }\end{array}$ & $\begin{array}{l}\text { Clemens, M. } \\
\text { A. }\end{array}$ & 2017 & Correlative & $\begin{array}{l}\text { Scholarly } \\
\text { paper }\end{array}$ \\
\hline
\end{tabular}




\section{REFERENCES}

The annotation (S) at the end of the bibliographical information of a cited work designates references that were included in the scoping review sample and are listed in the appendix.

Acuña González, G. (2016). Estructura y agencia en la migración infantil centroamericana [Structure and agency in Central American child migration]. Cuadernos Inter.c.a.mbio sobre Centroamérica y el Caribe., 13(1), 45-65. (S)

Amuedo-Dorantes, C. \& Puttitanun, T. (2016). DACA and the surge in unaccompanied minors at the US-Mexico border. International Migration, 54(4), pp. 102-117. DOI: 10.1111/imig.12250 (S)

Bacon, D. (2016). U.S. policies drive migration from Central America. Democratic Left, 43(4), 3-4. Retrieved from https://search.proquest.com (S)

Becker Herbst, R., Sabet, R. F., Swanson, A., Suarez, L. G., Marques, D. S., Ameen, E. J., \& Aldarondo, E. (2018). "They were going to kill me": Resilience in unaccompanied immigrant minors. The Counseling Psychologist, 46(2), 241-268. DOI: $10.1177 / 0011000018759769(\mathrm{~S})$

Betts, A. (2013). Survival migration: Failed governance and the crisis of displacement. Ithaca, NY: Cornell University Press.

Bhabha, J. (2001). Minors or aliens? Inconsistent state intervention and separated child asylumseekers. European Journal of Migration and Law, 3, 283-314.

Bryan, C. \& Denov, M. (2011). Separated refugee children in Canada: The construction of risk identity. Journal of Immigrant \& Refugee Studies, 9, 242-266. DOI: $10.1080 / 15562948.2011 .592806$

Cajina, R. \& Orozco, L. (2016). Falacias y realidades de una crisis humanitaria y política. Menores centroamericanos que migran en busca del "sueño americano" [Fallacies and 
realities of a humanitarian and political crisis. Central American minors migrating to seek the “American Dream”]. Boletín del Instituto Español de Estudios Estratégicos, 1, 459472. Retrieved from: https://dialnet.unirioja.es/servlet/articulo?codigo=5992480 (S)

Cao, M. (2017). Violencia infantil: La experiencia de niños y jóvenes indocumentados cruzando la frontera entre México y los Estados Unidos [Child violence: The experience of undocumented children and youth crossing the U.S.-Mexico border] (senior thesis). Trinity College, Hartford, CT. (S)

Carpenter, T. G. (2014, July 21). The child migrant crisis is just the latest disastrous consequence of America's drug war. The Washington Post. Retrieved from: https://washingtonpost.com/news/the-watch/wp/2014/07/21/the-child-migrant-crisis-isjust-the-latest-disastrous-consequence-of-americas-drug-war/?noredirect=on (S)

Casa Alianza Honduras, Pastoral de Movilidad Humana, \& Catholic Relief Services. (2016). Niñas y niños migrantes. Factores de expulsión y desafíos para su reinserción en Honduras [Child migrants. Factors pushing them out and challenges for their reinsertion in Honduras]. Retrieved from the Casa Alianza Honduras website: http://casaalianza.org.hn/images/documentos/CAH.2016/02.Infor.Especiales/02.\%20e_book_nias\% 20y\%20nios\%20migrantes.pdf (S)

Castles, S. (2007). The migration-asylum nexus and regional approaches. In S. Kneebone \& F. Rawlings (Eds.), New regionalism and asylum seekers: Challenges ahead (pp. 25-42). New York and Oxford: Berghahn Books.

Castles, S. (2013). The forces driving global migration. Journal of Intercultural Studies, 34(2), 122-140. DOI:10.1080/07256868.2013.781916 
Ceballos Castañeda, U. \& Del Carpio Ovando, P. S. (2017). Violencia, frontera sur y niñez migrante ["Violence, southern border, and child migration"]. Jóvenes en la Ciencia. Revista de divulgación científica, 3(2), 1460-1465. (S)

Central Intelligence Agency. (2018). El Salvador. In The world factbook. Retrieved July 7, 2018, from: https://cia.gov/library/publications/the-world-factbook/geos/es.html

Central Intelligence Agency. (2018). Guatemala. In The world factbook. Retrieved July 7, 2018, from: https://cia.gov/library/publications/the-world-factbook/geos/gt.html

Central Intelligence Agency. (2018). Honduras. In The world factbook. Retrieved July 7, 2018, from: https://cia.gov/library/publications/the-world-factbook/geos/ho.html

Ceriani Cernadas, P. (2012). Niñez detenida. Los derechos de los niños, niñas y adolescentes migrantes en la frontera México-Guatemala. Diagnóstico y propuestas para pasar del control migratorio a la protección integral de la niñez [Arrested childhood. The rights of migrant children and youth at the Mexico-Guatemala border. Assessment and recommendations for a shift from migratory control to the comprehensive protection of children]. Retrieved from the Centro de derechos humanos Fray Matías de Córdova website: http://cdhfraymatias.org/sitio/wpcontent/uploads/2014/11/InformeMexico_OK.pdf (S)

Chávez, L. \& Menjívar, C. (2010). Children without borders: A mapping of the literature on unaccompanied migrant children to the United States. Migraciones Internacionales, 5(3), $71-111$.

Chishti, M. \& Hipsman, F. (2014, June 13). Dramatic surge in the arrival of unaccompanied children has deep roots and no simple solutions. Retrieved from Migration Policy Institute website: https://migrationpolicy.org/article/dramatic-surge-arrivalunaccompanied-children-has-deep-roots-and-no-simple-solutions (S) 
Chishti, M. \& Hipsman, F. (2015). The child and family migration surge of summer 2014: A short-lived crisis with a lasting impact. Journal of International Affairs, 68(2), 95-114. (S)

Chishti, M. \& Hipsman, F. (2016, February 18). Increased Central American migration to the United States may prove an enduring phenomenon. Retrieved from Migration Policy Institute website: https://migrationpolicy.org/article/increased-central-americanmigration-united-states-may-prove-enduring-phenomenon (S)

Clemens, M. A. (2017). Violence, development, and migration waves: evidence from Central American child migrant apprehensions (Center for Global Development Working Paper 459). Retrieved from: https://www.cgdev.org/sites/default/files/violence-developmentand-migration-waves-evidence-central-american-child-migrant.pdf (S)

Consejo Nacional de Población [CONAPO, National Population Council]. (2016). Migración de niñas, niños y adolescentes: Antecedentes y análisis de información de la Red de módulos y albergues de los Sistemas DIF, 2007-2016 [Child and youth migration: Background and analysis of data collected from the network of shelters in the Integral Development of the Family Systems, 2007-2016]. Retrieved from the CONAPO website: https://www.gob.mx/conapo/articulos/migracion-de-ninas-ninos-y-adolescentesantecedentes-y-analisis-de-la-informacion-de-la-red-de-modulos-y-albergues-del-dif2007-2016-154653 (S)

Corbin, J. \& Strauss, A. (2015). Basics of qualitative research. Techniques and procedures for developing grounded theory (4th ed.). Thousand Oaks, CA: SAGE Publications Inc. 
Creswell, J. W. \& Poth, C. N. (2018). Chapter 4. Five qualitative approaches to inquiry. Qualitative inquiry \& research design $\left(4^{\text {th }}\right.$ ed., pp. $\left.65-108\right)$. Thousand Oaks, CA: SAGE Publications Inc.

Daudt, H. M. L., van Mossel, C. \& Scott, S. J. (2013). Enhancing the scoping study methodology: A large, inter-professional team's experience with Arksey and O’Malley's framework. BMC Medical Research Methodology, 13(48), 1-9. DOI:10.1186/1471$2288-13-48$

Donato, K. M. \& Sisk, B. (2015). Children's migration to the United States from Mexico and Central America: Evidence from the Mexican and Latin American Migration Projects. Journal on Migration and Human Security, 3(1), 58-79. (S)

El Paso Intelligence Center. (2014). Misperceptions of U.S. policy key driver in Central American migrant surge. Retrieved June 10, 2018 from: https://scribd.com/document/233856565/Leaked-EPIC-Document\#download (S)

El Salvador. (2009). Ley de protección integral de la niñez y adolescencia. Decreto No. 839 [Law for the comprehensive protection of childhood and adolescence. Decree No. 839]. $\begin{array}{lllll}\text { Retrieved } & \text { on } & \text { April } & 17, & 2018\end{array}$ https://www.asamblea.gob.sv/sites/default/files/documents/decretos/FC3868B6-5FEA440B-9949-414222C42FFD.pdf

Gaborit, M., Zetino Duarte, M., Orellana, C., \& Brioso, L. (2015). Capítulo 4. El Salvador. [Chapter 4. El Salvador.]. In K. Musalo, L. Frydman, \& P. Ceriani Cernadas (Eds.), Niñez. y migracion en Centro y Norte America: causas, políticas, prácticas y desafíos [Childhood and migration in Central and North America: Causes, policies, practices and 
challenges] (pp. 193-235). Retrieved from:

http://acnur.org/fileadmin/Documentos/Publicaciones/2015/9927.pdf (S)

Gatica López, G. A. (2016). Niñez migrante desde Centroamérica: los rostros de la baja inversión social pública. Revista Rupturas, 6(1), 91-123. (S)

Gerstein Science Information Centre. (n.d.). Systematic \& scoping reviews: Methdology behind the search strategies. Retrieved Marc h 26, 2018, from University of Toronto Libraries: https://guides.library.utoronto.ca/systematicreviews

Guatemala. (2003). Ley de protección integral de la niñez y adolescencia. Decreto número 272003 [Law for the comprehensive protection of childhood and adolesence. Decree No. 17-2003]. Retrieved on April 17, 2018 from http:/:/leydeguatemala.com/ley-deproteccion-integral-de-la-ninez-y-adolescen/definicion-de-ninez-y-adolescencia/11106/

Hiskey, J. T., Córdova, A., Orcés, D., \& Malone, M. F. (2016). Understanding the Central American refugee crisis. Why they are fleeing and how U.S. policies are failing to deter them. Retrieved from American Immigration Council website: https://americanimmigrationcouncil.org/research/understanding-central-americanrefugee-crisis

Honduras. (1996). Código de la niñez y la adolescencia. Decreto No. 73-96 [Code for childhood and adolescence. Decree No. 73-96]. Retrieved April 17, 2018 from http://www.poderjudicial.gob.hn/CEDIJ/Leyes/Documents/C\%C3\%b3digo\%20de\%20la $\% 20 \mathrm{Ni} \% \mathrm{C} 3 \%$ b1ez\%20y\%20la\%20Adolescencia\%20(Actualizado\%202014).pdf

Huijsmans, R. (2012). Beyond compartmentalization: A relational approach towards agency and vulnerability of young migrants. In A. Orgocka, \& C. Clark-Kazak (Eds.), Independent child migration-Insights into agency, vulnerability, and structure. New directions for 
child and adolescent development (Vol. 136, pp. 29-45). Hoboken, United States: John Wiley \& Sons, Incorporated.

Hurtado Paz y Paz, J., Girón Solorzano, C. L., \& Ibarra González, G. (2015). Capítulo 3. Guatemala. [Chapter 3. Guatemala.]. In K. Musalo, L. Frydman, \& P. Ceriani Cernadas, Niñez, migración, y derechos humanos [Childhood and migration in Central and North America: Causes, policies, practices and challenges] (pp. 150-192). Retrieved from: http://acnur.org/fileadmin/Documentos/Publicaciones/2015/9927.pdf (S)

Jaimez, D. (2017). The exclusion of Central American minors (UMC) under the refugee regime in the United States (honors thesis). Texas State University, San Marcos, Texas. (S)

Jones, R. C. (2017). The Central American child migration surge: A temporal and spatial investigation of its causes. The Latin Americanist, 333-360. DOI: 10.1111/tla.12133 (S)

Kandel, W. A., Bruno, A., Meyer, P. J., Seelke, C. R., Taft-Morales, M., \& Wasem, R. E. (2015). Unaccompanied alien children: Potential factors contributing to recent immigration. Current Politics and Economics of the United States, Canada, and Mexico, 17(3), 453483. (S)

Kennedy, E. (2014). No childhood here. Why Central American children are fleeing their homes. Retrieved from the American Immigration Council website: https://americanimmigrationcouncil.org/research/no-childhood-here-why-centralamerican-children-are-fleeing-their-homes (S)

Khashu, A. (2010). Children in transit: Results of interviews with Central American unaccompanied minors encountered in Mexico (documento de trabajo No. 21 del Centro de Estudios y Programas Interamericanos [Centre for Interamerican Studies and 
Programs Working Paper No. 21]). Retrieved from

http://interamericanos.itam.mx/working_papers/21KHASHU.pdf (S)

Kids in Need of Defense (KIND) \& Human Rights Center Fray Matías de Córdova. (2017).

Childhood cut short: sexual and gender-based violence against Central American migrant and refugee children. Retrieved from the KIND website: https://supportkind.org/wp-content/uploads/2017/06/Childhood-Cut-Short-KIND-SGBVReport_June2017.pdf (S)

Kranzler, J. H. (2011). Statistics for the terrified (5th ed.). Upper Saddle River, NJ: Pearson Prentice Hall.

Lorenzen, M. J. (2016). Características, tendencias y causas de la migración de niñas, niños y adolescentes desde, hacia y en tránsito por México, 2011-2016 [Characteristics, trends and causes of the migration of girls, boys and adolescents, from, to and through Mexico, 2011-2016]. In Consejo Nacional de Población (CONAPO), La situación demográfica de México 2016 [The Demographic Situation in Mexico in 2016] (pp. 183-207). Retrieved from the CONAPO website: https://www.gob.mx/conapo/documentos/la-situaciondemografica-de-mexico-2016 (S)

Lorenzen, M. (2017). The mixed motives of unaccompanied child migrants from Central America's Northern Triangle. Journal on Migration and Human Security, 5(4), 744-767. (S)

Machín Álvarez, M. (2015). Menores y migración: un acercamiento a los tipos de violencia en Centroamérica con énfasis en los y las menores migrantes no acompañados [Minors and migration: An introduction to the types of violence in Central America, with an emphasis 
on unaccompanied minor migrants]. Odisea. Revista de Estudios Migratorios., 2, 389411. (S)

Martín, F. (2014, July 8). "Salí para no ser asesinado" [“I left so I wouldn’t get murdered”]. El $\begin{array}{lll}\text { Universal } & \text { (Mexico). } & \text { Retrieved }\end{array}$ http://archivo.eluniversal.com.mx/estados/2014/impreso/-8220sali-para-no-ser-asesinado8221-95308.html (S)

McMillan, J. H. \& Wergin, J. F. (2006). Introduction to reading educational research. Understanding and Evaluating Educational Research (3rd ed.). Upper Saddle River, New Jersey: Pearson Merrill Prentice Hall.

Medrano, C. (2017). Securing protection for de facto refugees: The case of Central America's Northern Triangle. Ethics \& International Affairs, 31(2), 129-142. DOI:10.1017/S089267941700004

Meloni, F., Rousseau, C., Montgomery, C., \& Measham, T. (2014). Children of exception: Redefining categories of illegality and citizenship in Canada. Children \& Society, 28(4), 305-315. DOI:10.1111/chso.12006.

Musalo, K. \& Lee , E. (2017). Seeking a rational approach to a regional refugee crisis: Lessons from the summer 2014 "surge" of Central American women and children at the USMexico border. Journal on Migration and Human Security, 5(1), 137-179. (S)

Nazario, S. (2006). Enrique's journey. The story of a boy's dangerous odyssey to reunite with his mother. New York: Random House.

Neuman, W. L. (2006). Qualitative and quantitative sampling. Social research methods: Qualitative and quantitative approaches (6 ${ }^{\text {th }}$ ed., pp. 219-231). Boston and Toronto: Pearson \& Allyn and Bacon. 
Neuman, W. \& Robson, K. (2012). Chapter 6. Qualitative and quantitative measurement. In Basics of social research: Qualitative and quantitative approaches (2nd Canadian ed.). Toronto: Pearson Education Canada.

Nichols, B., Umana, K., Britton, T., Farias, L., Lavalley, R., \& Hall-Clifford, R. (2017). Transnational information politics and the "child migration crisis": Guatemalan NGOs respond to youth migration. Voluntas, 28, 1962-1987. DOI: 10.1007/s11266-017-9890-9 (S)

O’Higgins, A. (2012). Vulnerability and agency: Beyond an irreconcilable dichotomy for social service providers working with young refugees in the UK. In A. Orgocka, \& C. ClarkKazak (Eds.), Independent child migration-Insights into agency, vulnerability, and structure. New directions for child and adolescent development (Vol. 136, pp. 79-91). Hoboken, United States: John Wiley \& Sons, Incorporated.

Oppenheimer, A. (2014, July 4). EU se equivoca con niños migrantes [The United States are mistaken as far as child migrants are concerned.]. Reforma (Mexico), p. 20. Retrieved from: https:// search.proquest.com (S)

Orgocka, A. (2012). Vulnerable yet agentic: Independent child migrants and opportunity structures. In A. Orgocka, \& C. Clark-Kazak (Eds.), Independent child migrationInsights into agency, vulnerability, and structure. New directions for child and adolescent development (Vol. 136, pp. 1-11). Hoboken, United States: John Wiley \& Sons, Incorporated.

Orozco, M. \& Yansura, J. (2014). Understanding Central American migration: The crisis of Central American child migrants in context. Retrieved from the Inter-American Dialogue 
website: https://thedialogue.org/wp-

content/uploads/2015/05/FinalDraft_ChildMigrants_81314.pdf (S)

Planas, R. (2014). Don't blame Central American newspapers for influx of undocumented children. NACLA Report on the Americas, 47(3), pp. 6-7. Retrieved from https://search.proquest.com (S)

Preston, J. (2014, June 16). Migrants flow in South Texas, as do rumors. New York Times. Retrieved from: https://www.nytimes.com/2014/06/17/us/migrants-flow-in-south-texasas-do-rumors.html (S)

QSR International Pty Ltd. (2015). NVivo qualitative data analysis software (version 11 Plus).

Richmond, A. H. (1993). Reactive migration: Sociological perspectives on refugee movements. Journal of Refugee Studies, 6(1), 7-24.

Rivera, L. G., Ruelas, J. G., Herrera Cuello, U., \& Flores Pinto, C. (2015). Capítulo 2. Honduras. [Chapter 2. Honduras.]. In K. Musalo, L. Frydman, \& P. Ceriani Cernadas, Niñez y migración en Centro y Norte América: causas, politticas, prácticas y desafios [Childhood and migration in Central and North America: Causes, policies, practices and challenges] $\begin{array}{lll}\text { (pp. 104-149). } & \text { Retrieved }\end{array}$ http://acnur.org/fileadmin/Documentos/Publicaciones/2015/9927.pdf (S)

Robles, F. (2014, June 4). Wave of minors on their own rush to cross Southwest border. New York Times. Retrieved from: https://www.nytimes.com/2014/06/04/world/americas/waveof-minors-on-their-own-rush-to-cross-southwest-border.html (S)

Rodriguez, N., Urrutia-Rojas, X., \& Gonzalez, L. R. (2017). Unaccompanied minors from the Northern Central American countries in the migrant stream: Social differentials and institutional contexts. Journal of Ethnic and Migration Studies, 1-17. 
DOI: 10.1080/1369183X.2017.1404257 (S)

Rosenblum, M. R. (2015). Unaccompanied child migration to the United States.The tension between protection and prevention. Retrieved from the Migration Policy Institute website: https://migrationpolicy.org/research/unaccompanied-child-migration-unitedstates-tension-between-protection-and-prevention (S)

Rosenblum, M. R. \& Ball, I. (2016). Trends in unaccompanied child and family migration from Central America. Retrieved from the Migration Policy Institute website: https://migrationpolicy.org/research/trends-unaccompanied-child-and-family-migrationcentral-america (S)

Roth, B. J. \& Hartnett, C. S. (2018). Creating reasons to stay? Unaccompanied youth migration, community-based programs, and the power of "push" factors in El Salvador. Child and Youth Services Review, 1-8. DOI: 10.1016/j.childyouth.2018.01.026 (S)

Schmidt, S. (2017a). "They need to give us a voice": Lessons from listening to unaccompanied Central American and Mexican children on helping children like themselves. Journal on Migration and Human Security, 5(1), 57-81. (S)

Schmidt, S. G. (2017b). Child maltreatment and child migration: What unaccompanied migrant children from Central America and Mexico say about abuse and neglect and its implications for post-migration practice. In Lessons from listening to the voices of unaccompanied Central American and Mexican children. (banded doctoral dissertation, pp. 35-75). Saint Catherine University, Saint Paul, MN. (S)

Shear, M. D., Goodnough, A., \& Haberman, M. (2018, June 20). Trump retreats on separating families, but thousands may remain apart. New York Times. Retrieved from: 
https://www.nytimes.com/2018/06/20/us/politics/trump-immigration-children-executiveorder.html

Silva Hernández, A. L. (2014). Andares tempranos. Estrategias de movilidad de adolescentes "no acompañados" en la frontera México-Estados Unidos [Early wanderings. The mobility strategies of unaccompanied adolescents at the Mexico-United States border] (doctoral disseration). El Colegio de la Frontera Norte, Tijuana, Baja California, Mexico. (S)

"Sin nada, me tiré a la calle" ["With nothing to lose, I went to live on the street"]. (2014, July 8). El Universal. Retrieved from http://archivo.eluniversal.com.mx/estados/2014/impreso/8220sin-nada-me-tire-a-la-calle-8221-95309.html (S)

Stark, B., Shapiro, A., de la Pena, C. M., \& Ajl, J. (2015). Terra firma: Medical-legal care for unaccompanied immigrant Garifuna children. Harvard Journal of African American Public Policy, 97-104.

Stillman, A. (2016, February 10). 'All you can do is run': Central American children fleeing violence head for Mexico. The Guardian. Retrieved from: https://www.theguardian.com/global-development/2016/feb/10/central-americanchildren-fleeing-violence-mexico-guatemala-el-salvador-honduras

Stinchcomb, D. \& Hershberg, E. (2014). Unaccompanied Migrant Children from Central America. Context, Causes, and Responses (Center for Latin American \& Latino Studies Working Paper Series No. 7). Retrieved from: https://american.edu/centers/latinamerican-latino-studies/working-paper-series.cfm (S)

Suárez-Orozco, M. (2015). Las tres caras de Herodes: Éxodo de criaturas, migraciones 
catastróficas y vida en sombras. Multidisciplinary Journal of Educational Research, 5(1), 1-27. DOI: $10.4471 /$ remie.2015.01 (S)

Tello, A. M., Castellon, N. E., Aguilar, A., \& Sawyer, C. B. (2017). Unaccompanied refugee minors from Central America: Understanding their journey and implications for counselors. The Professional Counselor, 7(4), 360-374. DOI: 10.15241/amt.7.4.360 (S)

Torres, E. (2017). Understanding the causes of unaccompanied minors migrating to the US during 2014 (master's thesis). University of Massachusetts Boston. (S)

The United Nations. (1989). Convention on the rights of the child. Treaty Series, 1577,3.

Retrieved on April 17, 2018 from:

http://www.ohchr.org/EN/ProfessionalInterest/Pages/CRC.aspx

United Nations High Commissioner for Refugees. (1997). Guidelines on policies and procedures in dealing with unaccompanied children seeking asylum. Geneva: United Nations High Commissioner for Refugees. Retrieved on April 6, 2018 from: http://www.unhcr.org/publications/legal/3d4f91cf4/guidelines-policies-proceduresdealing-unaccompanied-children-seeking-asylum.html

United Nations High Commissioner for Refugees. (2014a). Children on the run. Unaccompanied children leaving Central America and Mexico and the need for international protection. Retrieved from: http://unhcr.org/about-us/background/56fc266f4/children-on-the-runfull-report.html (S)

United Nations High Commissioner for Refugees. (2014b). Arrancados de raíz [Uprooted]. Retrieved from: http://acnur.org/fileadmin/Documentos/Publicaciones/2014/9828.pdf (S) United Nations Office on Drugs and Crime. (n. d.). Homicide counts and rates (2000-2015). Retrieved June 29, 2018, from https://data.unodc.org/\#state: 
United Nations Office on Drugs and Crime. (2014). Global study on homicide 2013. Trends, contexts, data. Retrieved from: https://unodc.org/documents/data-andanalysis/statistics/GSH2013/2014_GLOBAL_HOMICIDE_BOOK_web.pdf

United Nations World Food Programme \& International Organization for Migration. (2016). Hunger without borders. The hidden links between food insecurity, violence and migration in the Northern Triangle of Central America. Retrieved from: https://wfp.org/node/647891 (S)

United States Customs and Border Protection. (2017, December). U.S. Border Patrol Southwest Border Apprehensions by Sector FY2017. Retrieved July 1, 2018, from: https://cbp.gov/newsroom/stats/usbp-sw-border-apprehensions-fy2017

United States Customs and Border Protection. (2018, June). Southwest Border Migration FY2018. Retrieved June 22, 2018, from https://cbp.gov/newsroom/stats/sw-bordermigration

United States Government Accountability Office. (2015). Information on migration of unaccompanied children from El Salvador, Guatemala, and Honduras. Retrieved from: https://gao.gov/products/GAO-15-362 (S)

United States Senate. Committee on Homeland Security \& Governmental Affairs. (2015). Stronger neighbors - Stronger borders: Addressing the root causes of the migration surge from Central America. Retrieved from the Homeland Security Digital Library: https://hsdl.org/?abstract\&did=789868 (S)

Varela Huerta, A. (2015). "Buscando una vida vivible": la migración forzada de niños de Centroamérica como práctica de fuga de la "muerte en vida". El Cotidiano, 194, 19-29. (S) 
Women's Refugee Commission. (2012). Forced from home: The lost boys and girls of Central America. Retrieved from:

https://www.womensrefugeecommission.org/uncategorized/2057-forced-from-home-thelost-boys-and-girls-of-central-america-background-and-report (S) 